\title{
A multi-model analysis of vertical ozone profiles
}

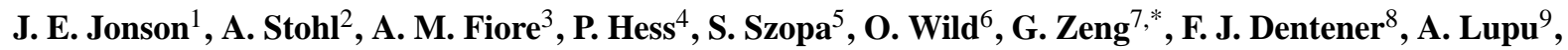 \\ M. G. Schultz ${ }^{10}$, B. N. Duncan ${ }^{11}$, K. Sudo ${ }^{12}$, P. Wind ${ }^{1}$, M. Schulz ${ }^{5}$, E. Marmer $^{8}$, C. Cuvelier ${ }^{8}$, T. Keating ${ }^{13}$, \\ A. Zuber ${ }^{14}$, A. Valdebenito ${ }^{1}$, V. Dorokhov ${ }^{15}$, H. De Backer ${ }^{16}$, J. Davies ${ }^{17}$, G. H. Chen ${ }^{18}$, B. Johnson ${ }^{19}$, \\ D. W. Tarasick ${ }^{17}$, R. Stübi ${ }^{20}$, M.J. Newchurch ${ }^{21}$, P. von der Gathen ${ }^{22}$, W. Steinbrecht ${ }^{23}$, and H. Claude ${ }^{23}$ \\ ${ }^{1}$ Norwegian Meteorological Institute, Oslo, Norway \\ ${ }^{2}$ NILU, Kjeller, Norway \\ ${ }^{3}$ Geophysical Fluid Dynamics Laboratory, NOAA, Princeton, NJ, USA \\ ${ }^{4}$ National Center for Atmospheric Research, Boulder, CO, USA \\ ${ }^{5}$ Laboratoire des Sciences du Climat et de l'Environnement, CEA/CNRS/UVSQ/IPSL, Gif-sur-Yvette, France \\ ${ }^{6}$ Lancaster Environment Centre, Lancaster University, UK \\ ${ }^{7}$ Centre for Atmospheric Science, University of Cambridge, UK \\ ${ }^{8}$ European Commission, DG-Joint Research Centre, Institute for Environment and Sustainability, Ispra, Italy \\ ${ }^{9}$ Center for research in Earth and Space Science, York University, Canada \\ ${ }^{10}$ ICG-2, Forchungszentrum-Julich, Germany \\ ${ }^{11}$ NASA Goddard Space Flight Center, Greenbelt, MD, USA \\ ${ }^{12} \mathrm{Grad}$. School of Environ. Studies, Nagoya University, Japan \\ ${ }^{13}$ Office of Policy Analysis and Review, Environmental Protection Agency, Washington DC, USA \\ ${ }^{14}$ Environment Directorate General, European Commission, Brussels, Belgium \\ ${ }^{15}$ Central Aerological Observatory, Moscow, Russia \\ ${ }^{16}$ Royal Meteorological Institute of Belgium (R.M.I.B.), Brussels, Belgium \\ ${ }^{17}$ Environmental Canada, Downsview, Canada \\ ${ }^{18}$ Central Weather Bureau, Taipei, Taiwan \\ ${ }^{19}$ NOAA/ESRL, Boulder, CO, USA \\ ${ }^{20}$ Federal Office of Meteorology and Climatology, MeteoSwiss, Payerne, Switzerland \\ ${ }^{21}$ Atmospheric Science Department, University of Alabama in Huntsville, Huntsville, AL, USA \\ ${ }^{22}$ Alfred Wegener Institute for Polar and Marine Research, Telegrafenberg A43, 14473 Potsdam, Germany \\ ${ }^{23}$ Met. Obs. Hohenpeissenberg, German Weather Service (DWD), Germany \\ *now at: National Institute of Water and Atmospheric Research, Lauder, New Zealand
}

Received: 14 October 2009 - Published in Atmos. Chem. Phys. Discuss.: 8 December 2009

Revised: 12 May 2010 - Accepted: 9 June 2010 - Published: 30 June 2010

\begin{abstract}
A multi-model study of the long-range transport of ozone and its precursors from major anthropogenic source regions was coordinated by the Task Force on Hemispheric Transport of Air Pollution (TF HTAP) under the Convention on Long-range Transboundary Air Pollution (LRTAP). Vertical profiles of ozone at 12-h intervals from 2001 are available from twelve of the models contributing to this study and are compared here with observed profiles from ozonesondes. The contributions from each major source region are analysed for selected sondes, and this analysis is supplemented by retroplume calculations using the FLEXPART Lagrangian
\end{abstract}

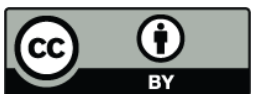

Correspondence to: J. E. Jonson (j.e.jonson@met.no) particle dispersion model to provide insight into the origin of ozone transport events and the cause of differences between the models and observations.

In the boundary layer ozone levels are in general strongly affected by regional sources and sinks. With a considerably longer lifetime in the free troposphere, ozone here is to a much larger extent affected by processes on a larger scale such as intercontinental transport and exchange with the stratosphere. Such individual events are difficult to trace over several days or weeks of transport. This may explain why statistical relationships between models and ozonesonde measurements are far less satisfactory than shown in previous studies for surface measurements at all seasons. The lowest bias between model-calculated ozone profiles and the

Published by Copernicus Publications on behalf of the European Geosciences Union. 
ozonesonde measurements is seen in the winter and autumn months. Following the increase in photochemical activity in the spring and summer months, the spread in model results increases, and the agreement between ozonesonde measurements and the individual models deteriorates further.

At selected sites calculated contributions to ozone levels in the free troposphere from intercontinental transport are shown. Intercontinental transport is identified based on differences in model calculations with unperturbed emissions and emissions reduced by $20 \%$ by region. Intercontinental transport of ozone is finally determined based on differences in model ensemble calculations. With emissions perturbed by $20 \%$ per region, calculated intercontinental contributions to ozone in the free troposphere range from less than $1 \mathrm{ppb}$ to $3 \mathrm{ppb}$, with small contributions in winter. The results are corroborated by the retroplume calculations. At several locations the seasonal contributions to ozone in the free troposphere from intercontinental transport differ from what was shown earlier at the surface using the same dataset. The large spread in model results points to a need of further evaluation of the chemical and physical processes in order to improve the credibility of global model results.

\section{Introduction}

While local and regional emissions sources are the main cause of air pollution problems worldwide, there is increasing evidence that many air pollutants are transported on a hemispheric or global scale, see TF HTAP (2007) and references therein. Observations and model predictions show the potential for intercontinental transport of a number of pollutants such as ozone and its precursors, fine particles, acidifying substances, mercury and POPs (Persistent Organic Pollutants). The Task Force on Hemispheric Transport of Air Pollution (TF HTAP) under the Convention on Longrange Transboundary Air Pollution (LRTAP) has been set up to study these processes. Under the framework of this task force a set of coordinated multi-model studies to address hemispheric transport issues have been defined. These multi model experiments were set up to give a first assessment of the source receptor relationships between the main source regions in the Northern Hemisphere in order to contribute to the revision of the Gothenburg protocol. The model experiments were defined so all models were run without major adaptations (native resolution, emissions etc.) with year 2001 meteorology. Emissions should be representative of year 2000/2001 conditions. Four regions are defined for source-receptor calculations, roughly representing Europe, North America, East Asia and South Asia. The source receptor relationships are calculated comparing the reference calculations with model calculations reducing emissions in the four regions by $20 \%$.
Trends in emissions and in pollutant concentrations differ significantly between the selected regions. In the European and North American regions emissions of the pollutants considered are generally decreasing as documented for the individual European and North American countries in WEBDAB (http://www.ceip.at/), whereas in East Asia and South Asia emissions are in general increasing as documented under ACCESS (http://www.cgrer.uiowa.edu/ EMISSION_DATA_new/summary_of_changes.html). As a result the relative distribution of the emissions between the selected regions will now already be markedly different from what they were in 2001, potentially changing the magnitude of transcontinental fluxes.

A description of the modelling experiment and key findings are published in the interim report from TF HTAP (TF HTAP, 2007). Furthermore, several papers are already published based on this dataset: The contribution from major northern mid-latitude source regions to Arctic pollution (Shindell et al., 2008); hemispheric transport and deposition of oxidised nitrogen (Sanderson et al., 2008); intercontinental source-receptor relationships for surface ozone (Fiore et al., 2009) and the impact of intercontinental ozone pollution on human mortality (Casper-Anenberg et al., 2009). A related paper (Lin et al., 2010) compares the fluxes of air pollutants in and out of the East Asian continents using a global model and two regional-scale models. Comparing model surface-ozone with observational data, Fiore et al. (2009) found a systematic overestimate of surface-ozone levels over the eastern United States and Japan in summer. This bias did not occur in the boreal spring and autumn months when intercontinental transport is strongest, reflecting a combination of more frequent cyclones venting the continents, stronger westerlies and a longer chemical lifetime of ozone compared to the summer months. The spatial average effects of foreign emission reductions in the receptor regions typically range from $0.7-0.9 \mathrm{ppb}$ in spring to $0.3-0.4 \mathrm{ppb}$ in the summer, but effects are likely to be larger on the western part of the continents/regions, closer to the foreign source areas. This was also shown, using the same dataset, in Reidmiller et al. (2009) focusing on North America, where the largest calculated effects of foreign emission reductions were seen in the western parts of the US.

In this paper we evaluate the model vertical profiles of ozone with an extensive measurement programme of vertical soundings for this species. The ozonesondes are primarily launched to study the depletion of the ozone layer in the winter and spring months. As a result measurements are often infrequent or missing in the summer and autumn months at many sites.

Model-calculated vertical profiles have been calculated for 32 sites selected based on the availability of ozone soundings. Model-calculated ozone profiles are compared to measurements focusing on a subset of four sites located in North America (Goose Bay, and Trinidad Head), Europe (Uccle) and Asia (Yakutsk). The ozonesonde sites presented here 
(with the exception of Goose Bay) are selected as they are located in the western part of the receptor continent/region in order to get a stronger signal from foreign sources. Results for other sites are also shown, but are discussed in less detail.

Advection of plumes from North America to Europe and from East Asia to North America is conceptually similar and usually involves lifting and subsequent advection in what are denoted as warm conveyor belts (see Stohl and Trickl (1999); TF HTAP (2007) and references therein). Across the Atlantic the transport time in the free troposphere is typically three to four days, and somewhat longer for transport across the Pacific (TF HTAP, 2007). Transport events of air pollutants from Asia to the western parts of North America typically occur 1-2 times per month (Liang et al., 2004). Such export events can have substantial impacts on concentrations in the free troposphere above the downwind continent. The impact of these transport events on surface sites is however less frequent and dilute (Zhang et al., 2009).

Transport of pollutants from Europe differs from advection across the Atlantic and the Pacific as lifting in frontal systems is less important. Even though advection across the Eurasian continent mainly takes place in the boundary layer, Wild et al. (2004) found the largest contributions to ozone from European sources in the mid troposphere. In the boundary layer ozone is depleted faster as a result of a combination of surface deposition and a shorter chemical lifetime. Yakutsk is located north of $60^{\circ} \mathrm{N}$, and may often be located too far north to be fully representative of advection across the Eurasian continent. Advection in general follows isentropic surfaces. Poleward advection (in this case from Europe to semi-Arctic Siberia) will tend to ascend in winter and early spring.

Ozone precursors emitted in the four regions considered will affect ozone levels throughout the entire tropospheric column at northern mid latitudes. Once in the free troposphere, the chemical lifetime of ozone is typically one month or more (TF HTAP, 2007; The Royal Society, 2008), much longer than the typical transport times between continents previously discussed. As shown in Huntrieser et al. (2005), plumes of intercontinental origin can be traced back to their sources, but due to the long lifetime of ozone it will eventually be virtually impossible to trace the ozone pollution in the free troposphere back to any specific source using measurements alone, but rather it will contribute to a general enhancement of tropospheric ozone affecting the northern mid latitudes as a whole. With the use of models, the origin of ozone in the free troposphere can be estimated as the difference between the reference run and a perturbed run. Different models provide different estimates on the origin of surface-ozone in the source receptor calculations as already shown by Fiore et al. (2009).

The advection of the pollutants are particularly sensitive to the exchange between the boundary layer and the free troposphere above. This sensitivity in turn will affect the chemical regime in which the pollutants are advected in the models.
In the free troposphere the pollutants are detached from the surface and dry deposition is no longer effective. With different timescales in the lifting/mixing process the $\mathrm{NO}_{\mathrm{x}}$-to-VOC (including $\mathrm{CH}_{4}$ ) ratio is likely to change, and thereby the potential for chemical ozone production/destruction. Comparing ozonesonde measurements and model calculations will give further insight to the combined effects of advection and ozone chemistry in the models.

With the use of trajectories, or tracer transport models, we can assess the likely origin and advection path of the pollutants. This information can enhance our understanding of the measurements and model calculations at the sonde sites, help explain differences between model results and also provides information on the predictability of ozone at different sites and height levels.

\section{Ozonesonde measurements}

With the exception of Yakutsk the ozonesonde data included in this study originate from the World Ozone and Ultraviolet Radiation Data Centre (WOUDC, http://www.woudc.org/). Ozonesonde measurement at Yakutsk have been made within the framework of the THESEO campaign and have been downloaded through the RETRO database (http://nadir.nilu. no/retro/). The most common type of ozonesondes currently in use is the electrochemical concentration cell (ECC). The ECC ozonesondes are manufactured by EnSci Corp. and Science Pump, with minor differences in construction and some variation in recommended concentrations of the potassiumiodide sensing solution and its phosphate buffer. At Tateno the KC96 Carbon-Iodine sensors are used. At Payerne and Hohenpeissenberg the Brewer-Mast ozonesondes were used (replaced by ECC sondes from 2002 at Payerne). For Payerne it has been shown in Stübi et al. (2008) that the two sonde types agree very well if the Brewer-Mast data are normalised to the nearby total ozone column (Dobson/Brewer). At all other sites ECC instrumentation is used. At both Uccle and Yakutsk EnSci-Z sondes were used with SST0.5 solutions. This is the solution recommended by the producer and that has been shown to give the best performance for this instrument when compared to a UV-photometer (Smit et al., 2007). At Goose Bay the EnSci-Z sondes were used with $1 \% \mathrm{KI}$ full buffer solution. This combination may result in an overestimation of a few percent, but this is largely corrected by the total ozone correction procedure. At Trinidad Head EnSci-2Z were used, along with the solution recommended by the producer. However, the sodium phosphate buffers are diluted to $1 / 10$ th of the standard $1 \%$ KI sensor solution recipe. At Taipei Science Pump model 6a sondes were used. When properly prepared and handled, ECC ozonesondes have a precision of 3-5\% and an absolute accuracy of about $10 \%$ in the troposphere (Smit et al., 2007; Deshler et al., 2008). After comparing a range of ozonesondes, Deshler et al. (2008) found that the range in the measurements 
Table 1. Models providing vertical profiles of ozone for the TF HTAP intercomparison. Documentation of the models can be found at http://www.htap.org/ under the heading: Model Descriptions. Only the 7 first models (in bold) provided vertical profiles for the SR20\% scenarios.

\begin{tabular}{|c|c|c|c|c|}
\hline Model & $\begin{array}{c}\text { Resolution } \\
\text { (lat long layers) }\end{array}$ & upper bound. & Institution & $\begin{array}{l}\text { contact person } \\
\text { HTAP }\end{array}$ \\
\hline MOZARTGFDL $2^{1}$ & $1.9^{\circ} \times 1.9^{\circ} \times 28$ & $0.66 \mathrm{hPa}$ & GFDL, USA & Arlene Fiore \\
\hline CAMCHEM $3311 \mathrm{~m} 13$ & $2.5^{\circ} \times 2.5^{\circ} \times 30$ & $2.5 \mathrm{hPa}$ & NCAR, USA & Peter Hess \\
\hline LMDz-INCA vSSz & $2.5^{\circ} \times 3.8^{\circ} \times 19$ & $3 \mathrm{hPa}$ & CEA, France & Sophie Szopa \\
\hline EMEP rv2.6 ${ }^{2}$ & $1.0^{\circ} \times 1.0^{\circ} \times 20$ & $100 \mathrm{hPa}$ & met.no, Norway & Jan E. Jonson \\
\hline FRSGC/UCI & $2.8^{\circ} \times 2.8^{\circ} \times 37$ & $2 \mathrm{hPa}$ & Univ. Lancaster, UK & Oliver Wild \\
\hline САМСНEM 3514 & $2.5^{\circ} \times 2.5^{\circ} \times 30$ & $2.5 \mathrm{hPa}$ & NCAR, USA & Peter Hess \\
\hline TM5-JRC-cy2-ipcc & $1.0^{\circ} \times 1.0^{\circ} \times 25$ & $0.48 \mathrm{hPa}$ & JRC, Italy & Frank Dentener \\
\hline UM CAM-v01 ${ }^{1}$ & $2.5^{\circ} \times 3.8^{\circ} \times 19$ & $4.6 \mathrm{hPa}$ & Univ. Cambridge, UK & Guang Zeng \\
\hline * MOZECH-v16 & $2.8^{\circ} \times 2.8^{\circ} \times 31$ & $10 \mathrm{hPa}$ & FZ Jülich, Germany & Martin Schultz \\
\hline GEMAQ-v1p0 & $4.0^{\circ} \times 4.0^{\circ} \times 28$ & $10 \mathrm{hPa}$ & York Univ., Canada & Alexandru Lupu \\
\hline GMI-v02f & $2.0^{\circ} \times 2.5^{\circ} \times 42$ & $0.01 \mathrm{hPa}$ & NASA GSFC, USA & Bryan Duncan \\
\hline CHASER v3.0 & $2.8^{\circ} \times 2.8^{\circ} \times 32$ & ca. $3 \mathrm{hPa}$ & Nagoya Univ., Japan & Kengo Sudo \\
\hline
\end{tabular}

\footnotetext{
1 No chemistry above tropopause level

2 Interpolated from $100 \times 100 \mathrm{~km}^{2}$ polar stereographic grid, N. Hemisphere only. No chemistry above approximately $14000 \mathrm{~m}$. Prescribed $\mathrm{O}_{2}$ and $\mathrm{NO}_{\mathrm{y}}$ above $30 \mathrm{hPa}$.
}

were generally within $2 \%$, increasing to $4-5 \%$ near the surface, in the tropopause region and where ozone gradients were large. The ozone sensor response time $\left(e^{-1}\right)$ of about 25 seconds gives the sonde a vertical resolution of about 100 metres for a typical balloon ascent rate of $4 \mathrm{~m} / \mathrm{s}$ in the troposphere. In the past the accuracy of the ozonesondes was occasionally affected by the interference from $\mathrm{SO}_{2}$, particularly in Europe. As $\mathrm{SO}_{2}$ emissions have been reduced, this was probably not the case in 2001 .

\section{The model setup and definition of the model scenario}

The twelve models listed in Table 1 provided model calculated vertical profiles of $\mathrm{O}_{3}, \mathrm{CO}, \mathrm{NO}$ and $\mathrm{NO}_{2}$ on the HTAP server.

We use the reference simulation (SRref) and a set of simulations in which emissions of $\mathrm{NO}_{\mathrm{x}}, \mathrm{CO}$, and NMVOC were reduced together by $20 \%$ within each of four regions (denoted here as SR20\%): North America (SR20\%NA, 125W to $60 \mathrm{~W}$ and $15 \mathrm{~N}$ to $55 \mathrm{~N}$ ), Europe (SR20\%EU, $10 \mathrm{~W}$ to $50 \mathrm{E}$ and $25 \mathrm{~N}$ to $65 \mathrm{~N}$ ), East Asia (SR20\%EA, $95 \mathrm{E}$ to $160 \mathrm{E}$ and $15 \mathrm{~N}-50 \mathrm{~N}$ ) and South Asia (SR20\%SA, $50 \mathrm{E}$ to $95 \mathrm{E}$ and $5 \mathrm{~N}$ to $35 \mathrm{~N}$ ). The first seven models (in bold) listed in Table 1 have provided vertical profiles also for the SR20\% scenarios. The model groups used their own emission estimates in the SRref model simulations.

The analysis of these simulations is supplemented by retroplume calculations with the Lagrangian particle dispersion model FLEXPART version number 8.0 (see Stohl et al. (1998, 2003, 2005, 2007) and http://transport.nilu.no/flexpart for further references) driven by meteorological input data from the European Centre for Medium-Range Weather Forecasts (ECMWF, 2002). These calculations provide quantitative dispersion model runs in time-reversed mode including full turbulence and convection parametrisations. 60000 particles are released every $250 \mathrm{~m}$ in the atmospheric column above the ozonesonde sites from the surface to a $12.5 \mathrm{~km}$ altitude. For every height interval, the particles are separately traced backward in time for 20 days, calculating what is denoted as potential emission sensitivity (PES) function in $\mathrm{s} \mathrm{kg}^{-1}$. Since emissions occur predominately at or near the surface, the PES near the surface is particularly important. We therefore show PES values for a so-called footprint layer below $100 \mathrm{~m}$ above the surface. By multiplying the PES values with emission fluxes (in $\mathrm{kg} \mathrm{m}^{-2} \mathrm{~s}^{-1}$ ) for carbon monoxide taken from the EDGAR emission inventory, potential source contribution maps are obtained, which show where surface emissions entered the air mass arriving later at the receptor. Integration of potential source contributions over continental areas yields simulated carbon monoxide mixing ratios at the ozonesonde site. These have been examined for the different continental source regions as a function of altitude, to identify altitude layers with strong influence from foreign emissions.

\section{Model results}

Previous analysis of the TF HTAP model inter-comparison has mainly focused on the effects on surface concentrations.

The models have provided vertical profiles at 32 stations, but since they are all located in the northern mid latitudes, we focus on the impacts of emissions from the NA, EU, and EA 


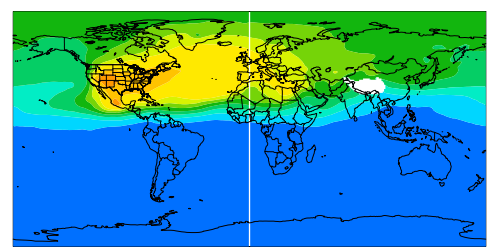

a) SRref - SR20\%NA

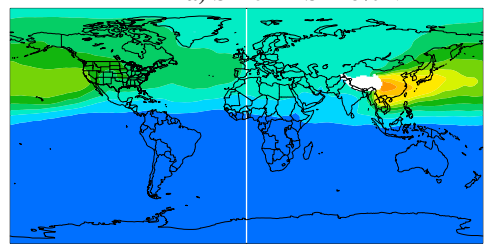

c) SRref - SR20\%EA
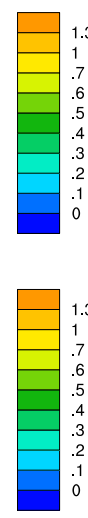

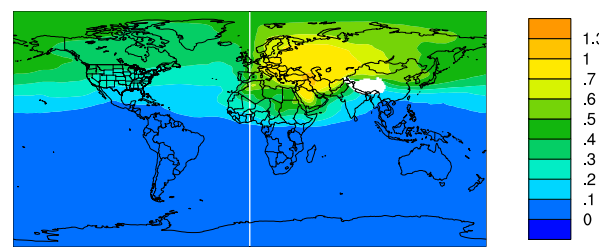

b) SRref - SR20\%EU

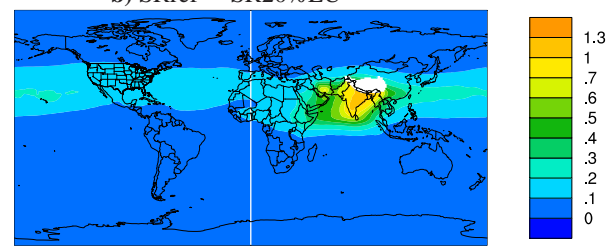

d) SRref - SR20\% SA

Fig. 1. Effects of emission reductions (2001) in North America (a), Europe (b), East Asia (c), and South Asia (d) on ozone (ppb) in the lower free troposphere $(750 \mathrm{hPa})$ averaged over one year (2001) calculated with the model ensemble of the first 7 models listed in Table 1 . The zero contribution over the Himalayas is caused by the $750 \mathrm{hPa}$ surface being below the surface here.

regions. As seen below, the contribution from emissions in SA to tropospheric ozone is small at northern mid latitudes.

Figure 1 shows the change in annual mean ozone, calculated with the first seven models listed in Table 1, in the lower free troposphere $(750 \mathrm{hPa})$ when $\mathrm{NO}_{\mathrm{x}}, \mathrm{CO}$, and $\mathrm{NMVOC}$ are decreased by $20 \%$ in the NA, EU, EA and SA regions. Emissions from NA, EU and EA are mostly advected in the westerlies, and consequently regions east of the source areas are the most affected. However, effects can be seen throughout the northern mid and high latitudes at this level. Emissions from SA are to a large extent advected westward with the monsoon circulation.

The vertical distribution of the contribution to ozone, averaged above the receptor regions, are shown in Fig. 2 as a function of month. The contributions from other regions/continents are mostly evident in the middle and upper troposphere. A noticeable exception are the contributions from EU, where contributions are largest in the lower troposphere. There are marked seasonal variations in the contributions. In the lower troposphere the largest contributions are mostly found in spring, and the smallest contributions in summer. The lower contributions in summer are due to a shorter lifetime of ozone and to the greater extent of southerly flow over the regions in this season. In the upper troposphere the maximum contribution is calculated in summer, probably reflecting stronger deep convection over source regions.

Below we evaluate the ozone simulations with the ozone soundings. Furthermore we highlight long-range transport events, as diagnosed from differences between the ozone vertical profiles in the SRref and SR20\% scenarios, for selected dates at Goose Bay, Uccle, Trinidad Head and Yakutsk. This analysis is extended to also include retroplume calculations with the FLEXPART model.

\subsection{Model evaluation by ozonesondes}

In Figs. 3 to 6 ozonesondes and vertical profiles calculated with the models listed in Table 1 are compared for Goose Bay in eastern Canada, Uccle in Belgium, Trinidad Head on the west coast of USA and Yakutsk in Siberia. The data have been aggregated into the lower, middle and upper troposphere. Only days with measurements are included in the comparison. The data are shown separately for each season, where Winter includes January, February and December (December also for 2001). Spring: March, April and May, Summer: June, July, August and Autumn: September, October, November. Figures 7 to 10 show the daily range (range between highest and lowest value) of ozone calculated by the same models for the same height intervals. Daily range for additional sites, Payerne (Switzerland) and Hohenpeissenberg (southern Germany) in EU, Huntsville (east/central USA) and Edmonton (west/central) Canada in NA, Tateno (Japan) and Taipei (Taiwan) in EA and Ny Ålesund (Spitzbergen)and Alert (northern arctic Canada) are also shown in the supplementary material. In these figures the sonde measurements are marked as black dots. At the right hand side of Figs. 7 to 10 specific events/episodes are highlighted. These events/episodes are described in more detail in later sections. There are large differences in the frequencies of sondes released at the sites, but at most sites the frequency of sonde measurements is highest in winter and spring. At Uccle there are sonde measurement made almost every second day throughout the year, whereas for the other sites sonde measurements are often infrequent or missing, particularly in the summer months. As a result the comparisons with measurements are based on limited data for some of the sites.

The data presented in Figs. 3 to 6 are supplemented by Taylor diagrams in Figs. 11. Additional Taylor diagrams 

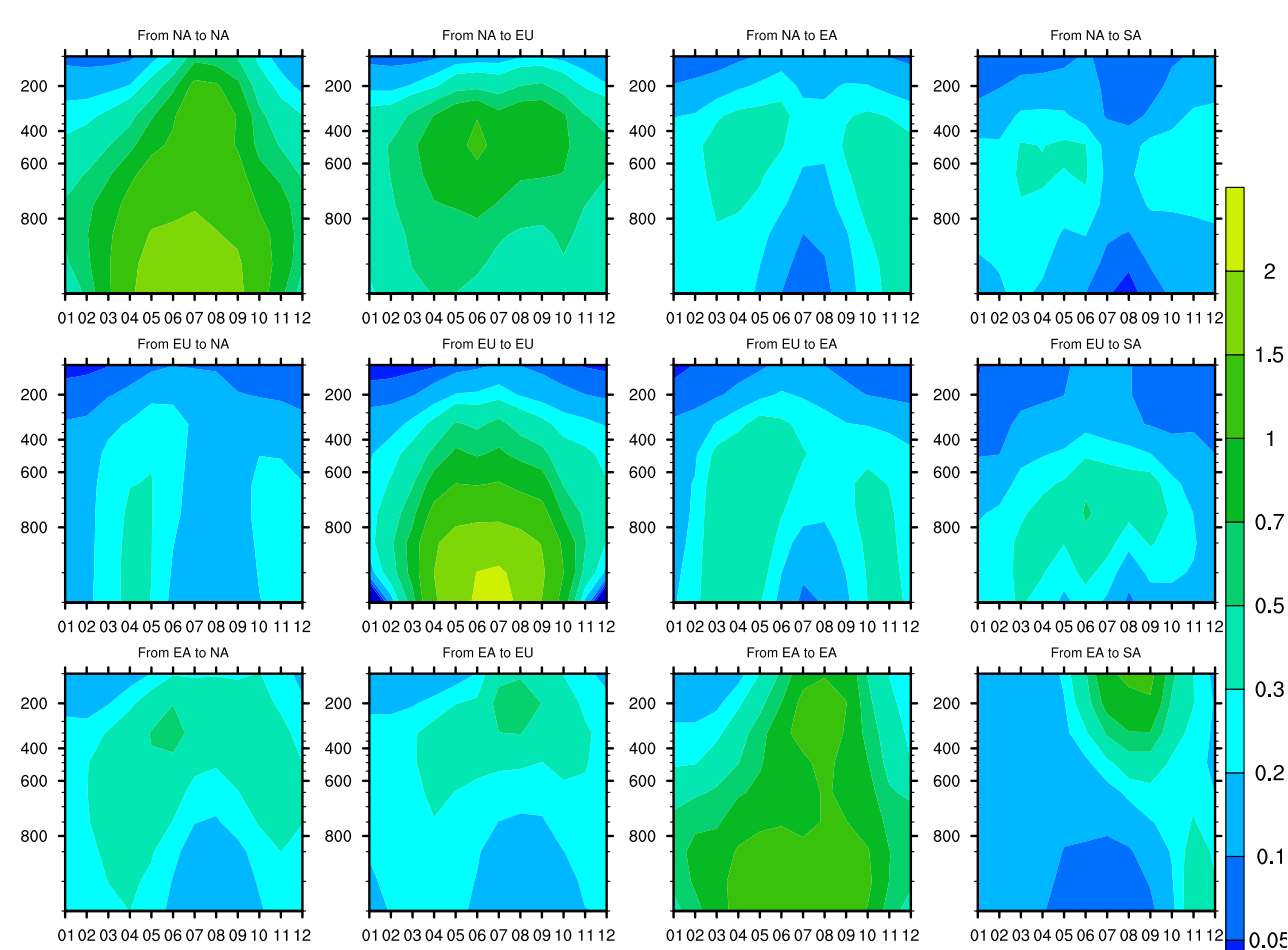
From EA to EA
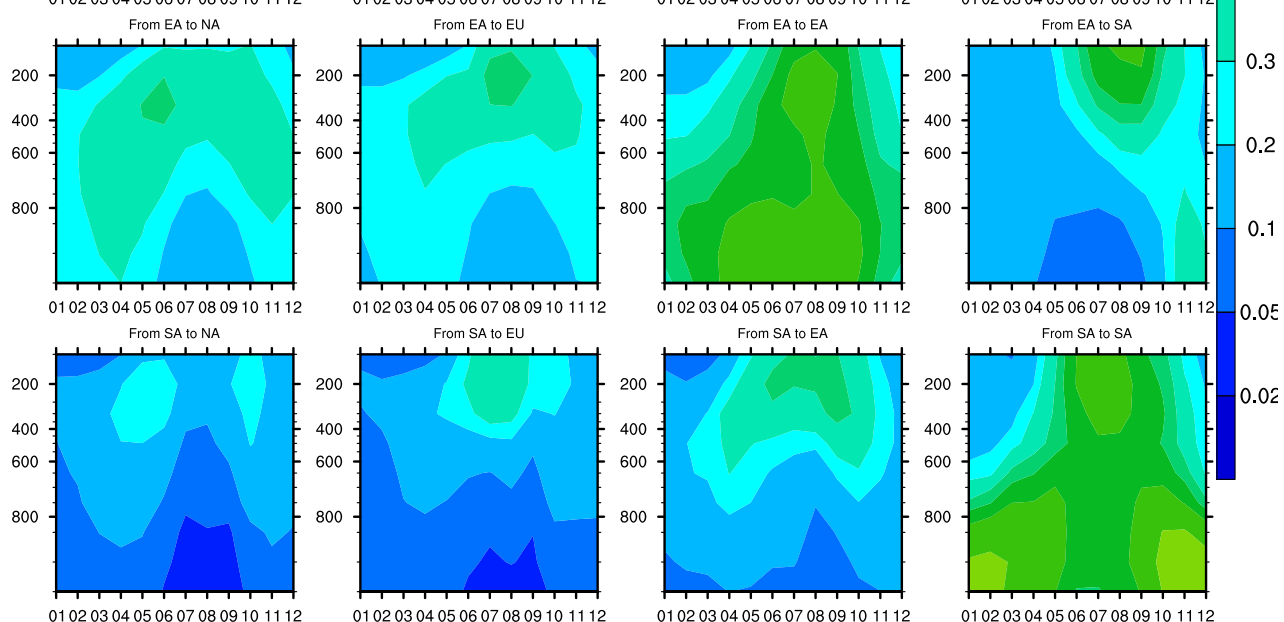

Fig. 2. Effects of emission reductions (2001) as a function of height (hPa) from North America (NA), Europe (EU), East Asia (EA) and South Asia (SA) on ozone (ppb) as a function of month number. The top row shows the effects averaged over the NA domain, the second row shows the effects over the EU domain, the third row shows the effects over the SA domain and the last row shows the effects over the SA domain. averaged over one year calculated with the model ensemble of the first 7 models listed in Table 1.

are also shown in the supplementary material. See figure captions for an interpretation of the Taylor diagrams. Details about the use of Taylor diagrams are provided in Taylor (2001) and on the NCL (NCAR Command Language) homepage: (http://www.ncl.ucar.edu/Applications/ taylor.shtml). The Taylor diagrams are not divided into season, but as there are more measurements in winter and early spring there is a clear bias to the winter months in the Taylor diagrams. In addition to correlation with measurements the Taylor diagrams show the RMS error and the normalised standard deviations. There is considerable scatter in the results presented in the Taylor diagrams. As ozonesonde errors are expected to be only a few percent (section 2) the scatter can be ascribed to model errors. One general feature for virtually all models and sites is that the standard deviation is low in the upper troposphere when compared to the ozonesondes. (In the Taylor diagrams this results in a short radial distance from the origin). This may be related to coarse model res- olution (both vertical and horizontal) resulting in too little variability in the UTLS region. With a low chemical activity the range in calculated ozone is small in the autumn and winter months, as seen inof Figs. 7 to 10 and the supplementary material. As the chemistry becomes active in the spring and summer months, the spread in model results increases, and clear over and underestimations compared to ozone soundings and/or model median results become more apparent in the daily calculated ozone. A notable exception is the upper troposphere at the polar sites Ny Ålesund and Alert (supplementary material). Here there is a large spread in model results and measurements in the winter and spring months. This is caused by the low tropopause in polar regions, and as a result the 500 to $700 \mathrm{hPa}$ altitude range is often (partially) in the stratosphere. The seasonal averages for most models are well within $20 \%$ compared to the sonde measurements in the lower and middle troposphere. In the upper troposphere the bias is often higher (eee Figs. 3 to 6) The spread in model 


\section{Winter 2001}
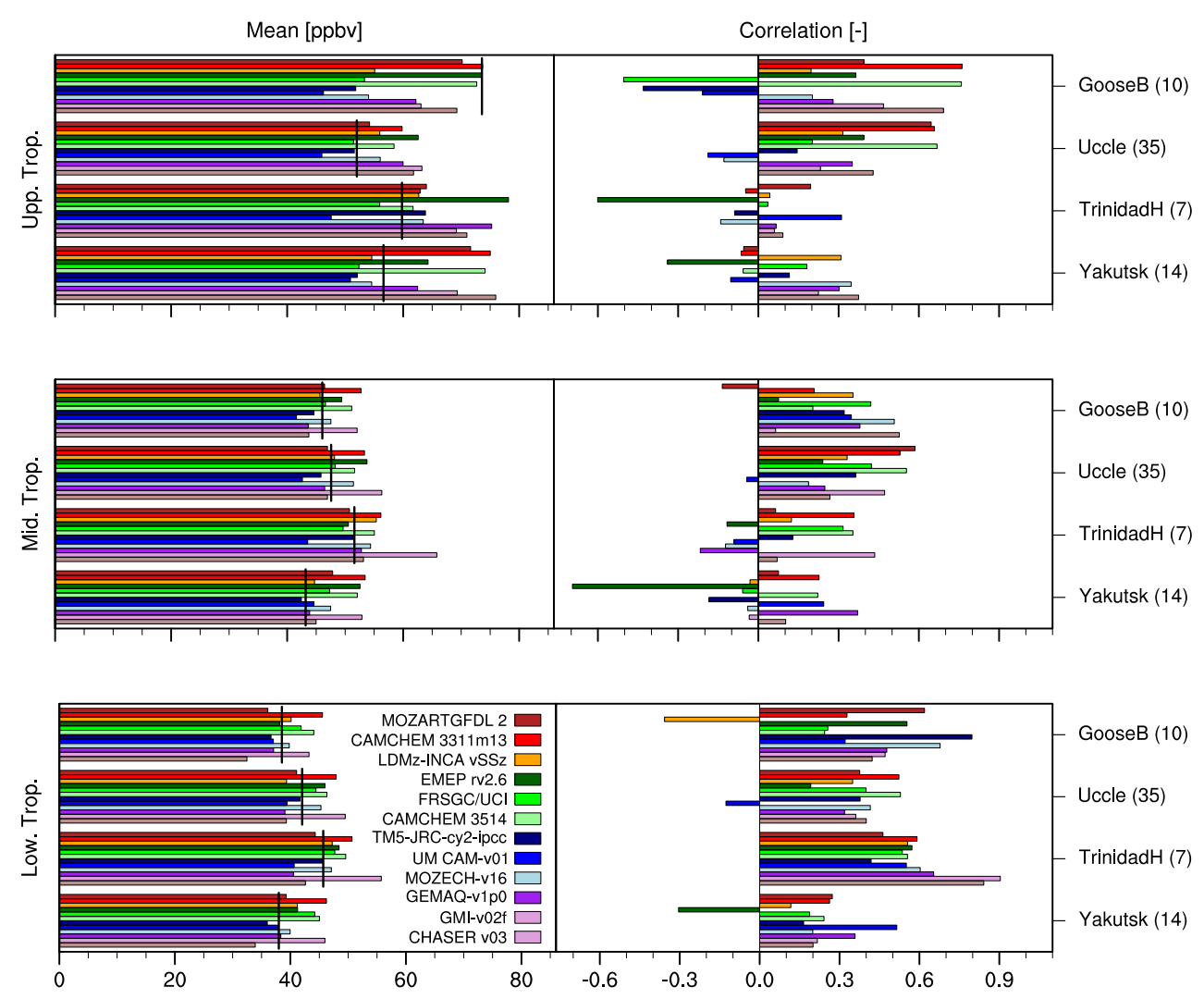

Fig. 3. Measured and model-calculated ozone (ppb) in winter (January, February, December) for the lower troposphere (900-700hPa), middle troposphere $(700-500 \mathrm{hPa})$ and upper troposphere $(500-300 \mathrm{hPa})$ for the selected ozonesonde sites. Concentrations to the left (solid lines crossing the model calculations are measurements), correlations to the right. The numbers behind the site name refer to the number of soundings available for comparison in Winter. GooseB. is short for Goose Bay, TrinidadH is short for Trinidad Head.

results is caused by a combination of differences in chemical formulation and by differences in the advection emphasised as the range between low and high ozone regions increases.

Based on the comparison with measurements in Figs. 3 to 6 and the Taylor diagrams in Figures 11, Goose Bay shows the best model performance. This site is on the eastern side of the North American continent with major North American source regions close enough for the plumes reaching this site to maintain their identity in the models, but are still sufficiently far away for lifting and mixing into the free troposphere to take place, resulting in relatively low RMS errors and high correlations with the measurements compared to the other sites. The models also perform reasonably well for Uccle. These soundings are made directly above one of the highest emitting regions in Europe, and the lower troposphere results are particularly affected by these local and regional sources. For Trinidad Head it is unfortunate that there are no sondes released after May 18. Even though domestic (North American) sources contribute the most for extended periods in summer and autumn in the lower and partially in the middle troposphere, the transcontinental contributions are mostly dominant compared to the contributions from domestic sources (see discussion in Sect. 4.2), and model performance is not as good as Goose Bay and Uccle at this site.

For other low and mid latitude sites shown in the supplementary material (Payerne, Hohenpeissenberg, Huntsville, Tateno and Taipei) model performance compared to measurements is largely comparable to what has been shown for Uccle, Goose Bay and partially Trinidad Head.

The least satisfactory performance is in general seen for the high latitude and arctic sites Yakutsk, Edmonton and Ny Ålesund, where there are virtually no correlations between models and ozonesonde measurements in winter and spring at all height levels (At the arctic site Alert model performance is however comparable to mid latitude sites). Ozone levels here are likely to originate from more aged air-masses and the poorer model performance may reflect the inability of the models to trace individual plumes at these long timescales. 
Spring 2001
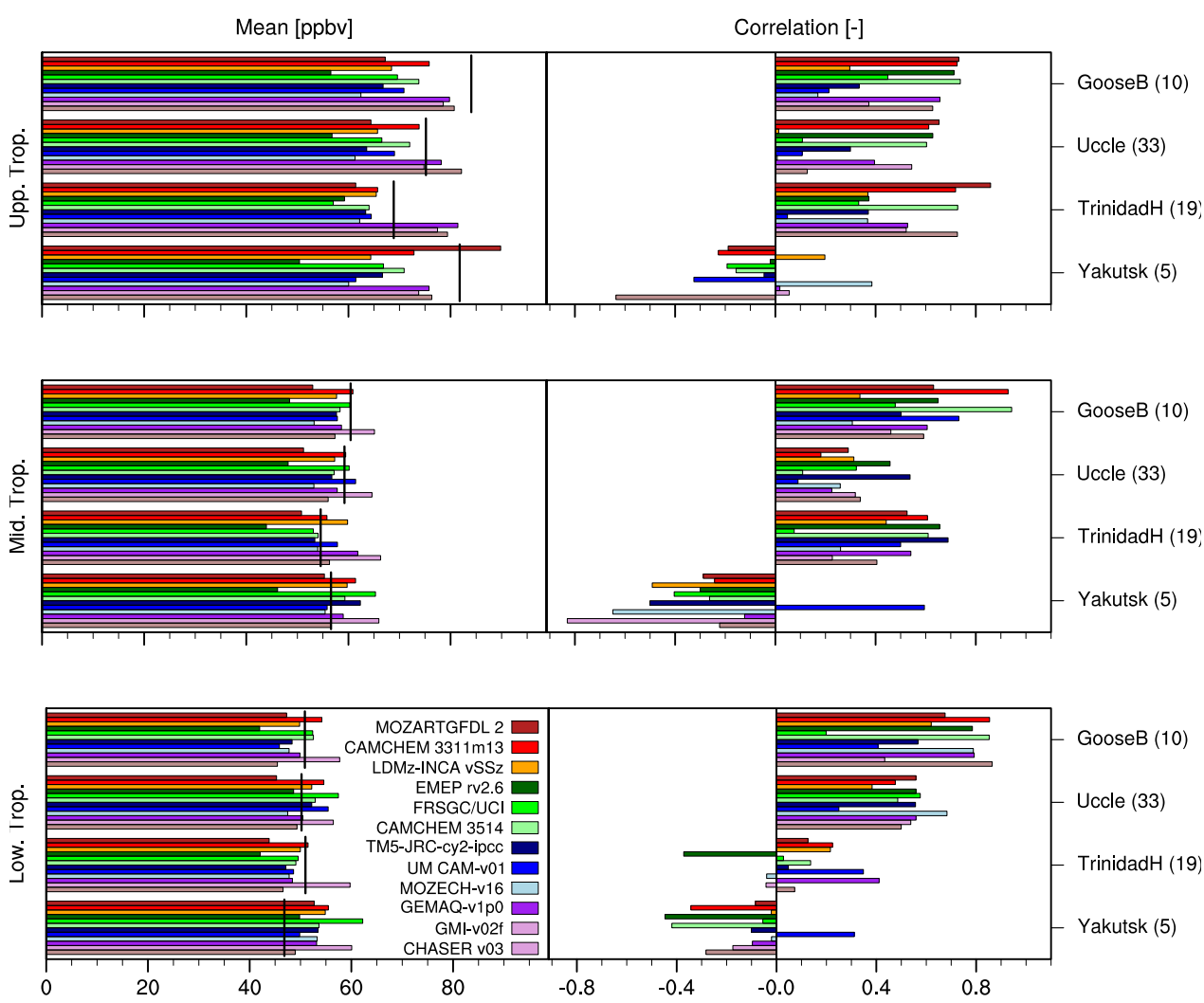

Fig. 4. Measured and model-calculated ozone ( $\mathrm{ppb}$ ) in spring (March, April, May) for the lower troposphere (900-700 hPa), middle troposphere $(700-500 \mathrm{hPa})$ and upper troposphere $(500-300 \mathrm{hPa})$ for the selected ozonesonde sites. Concentrations to the left (solid lines crossing the model calculations are measurements), correlations to the right. The numbers behind the site name refer to the number of soundings available for comparison in Spring. GooseB. is short for Goose Bay, TrinidadH is short for Trinidad Head.

As shown by the range in calculated ozone in Figs. 7 to 10 , and in the supplementary material, there are significant differences in the ability of the models to reproduce ozone levels at the different sites. Even though the seasonal differences between ensemble model means and sonde measurements are moderate, the day-by-day difference is considerably larger. Most of the sonde measurements fall within the displayed model range. In the lower and middle troposphere the range is narrower in the autumn and winter months. Measurements outside this range reflect specific events not included in the models. Nearly all of the incidents where measured ozone is notably outside the range, are in the upper troposphere, and are probably associated with misplaced tropopause heights or stratospheric intrusion events. The low value measured in late May at Uccle (Fig. 8) was probably caused by ozone titration, as regional $\mathrm{NO}_{\mathrm{x}}$ emissions are very high in this part of Europe.

Fiore et al. (2009) and Reidmiller et al. (2009) show the models have considerable skills in reproducing measured ozone for surface sites. In the boundary layer the lifetime of ozone is of the order of days only, and ozone is strongly affected by regional sources. The subset from the same set of models, included in this study, have far more difficulty in accurately reproducing ozone variability in the free troposphere. Similar results were also demonstrated in Tarasick et al. (2007) for two Canadian operational air-quality models (not represented in this study) and by Tong and Mauzerall (2006) for the community AQ model CMAQ. In Stevenson et al. (2006) it was shown that a model ensemble was able to reproduce the monthly mean ozone levels in the free troposphere. As shown in Figs. 3 to 6 and in Figs. 7 to 10, and in the figures in the supplementary material, most models (and subsequently the model mean) included here reproduce the mean abundances and seasonal cycle of ozone in a similar fashion to what was shown in Stevenson et al. (2006).

Liu et al. (2009) calculated the correlations between nearby pairs of sonde stations. They found low correlations near the surface indicating that local and regional effects are important here. From the surface correlations rose sharply to a local maximum in the lower troposphere. This implies that the measurements here will be representative for a larger area, reducing the disadvantage of using relatively coarse 


\section{Summer 2001}
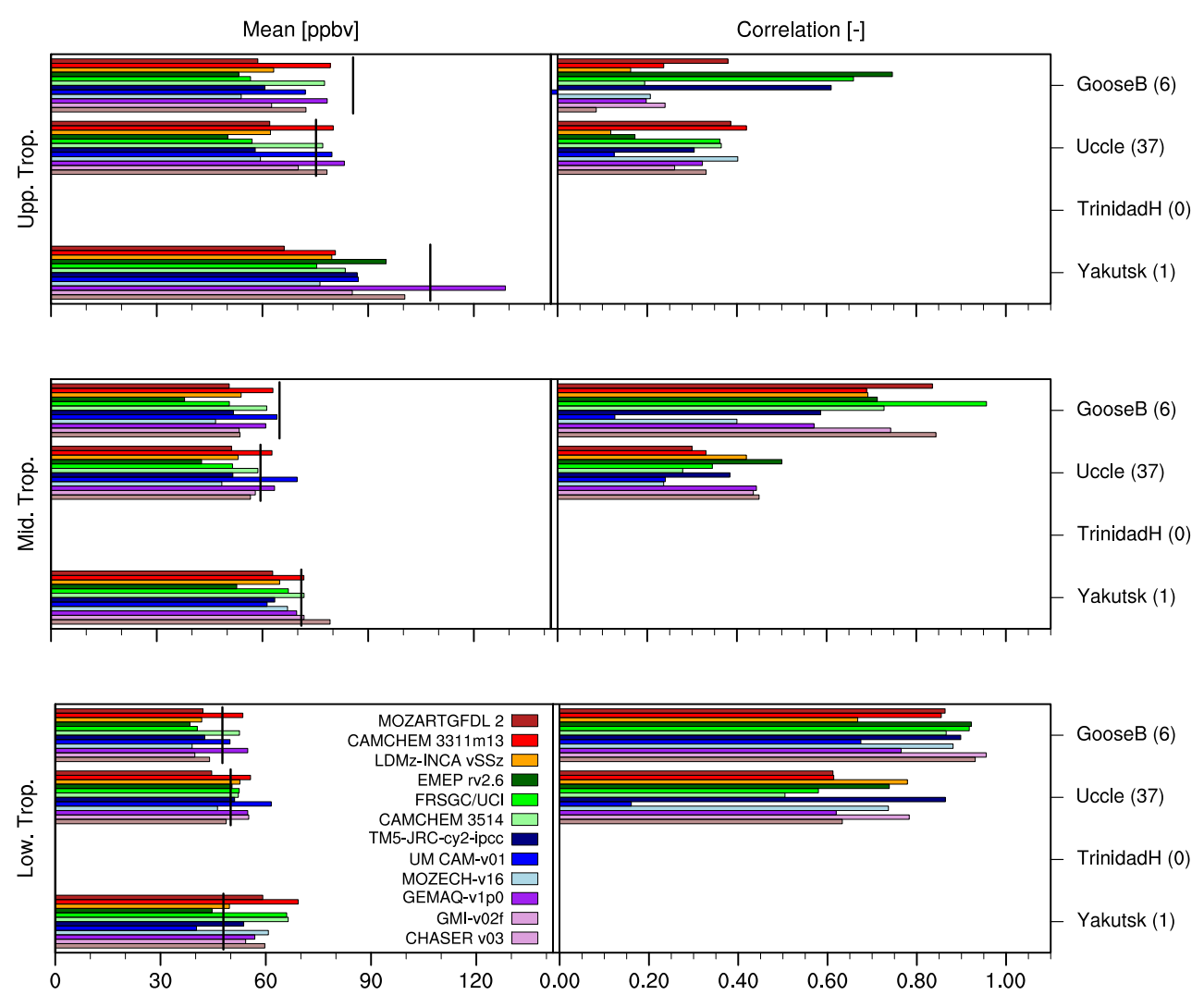

Fig. 5. Measured and model-calculated ozone (ppb) in summer (June, July, August) for the lower troposphere (900-700 hPa), middle troposphere $(700-500 \mathrm{hPa})$ and upper troposphere $(500-300 \mathrm{hPa})$ for the selected ozonesonde sites. Concentrations to the left (solid lines crossing the model calculations are measurements), correlations to the right. The numbers behind the site name refer to the number of soundings available for comparison in Summer. GooseB. is short for Goose Bay, TrinidadH is short for Trinidad Head.

models, but assuming that errors will propagate in space (and time) the extensive spatial range of influence for long lived pollutants may be too large for the models to reproduce.

There are marked differences between the individual sites in the model statistics as RMS errors and correlations with measurements. We believe these differences largely reflects the proximity of the dominant sources affecting the sites. With the largest contributions from transcontinental sources, located much further away, the identity of the ozone plumes are partially lost as they are advected over large distances. This loss of identity is likely to be caused by a combination of factors such as inaccuracies in the meteorological driver, inaccuracies stemming from the interpolation in time of the meteorological fields, the parameterisation of the advection processes in the CTMs and the coarse grid resolution used in the models. The lack of stratification in the model-calculated profiles compared to the ozonesondes as seen inof Figs. 12a, 13a, 14a and 15a may serve as an illustration of such effects. Furthermore uncertainties in emissions and chemistry will add to the lack of agreement between models and mea- surements. Such errors will propagate in time. This could in part explain the high RMS errors and low correlations at some sites as discussed above.

There is generally less agreement between models and measurements in the upper troposphere. In particular in the upper troposphere intrusion of stratospheric air will bring air with high ozone content to the sites. This is not always well represented in dynamical models, particularly those with moderate resolutions. Moreover, as already noted, the lifetime of ozone is much longer in the upper troposphere. Model discrepancies in the upper troposphere will mostly be due to poor resolution of the timing, location and magnitude of stratospheric intrusions.

At lower latitudes ozone levels are usually low throughout the tropospheric column. Thus air-masses of tropical or subtropical origin will in general have a low ozone content that may not be captured by the models, possibly as a result of model inability to capture deep convection.

As noted in Sect. 2, ozone levels in the boundary layer and lower troposphere could be subject to local effects not 

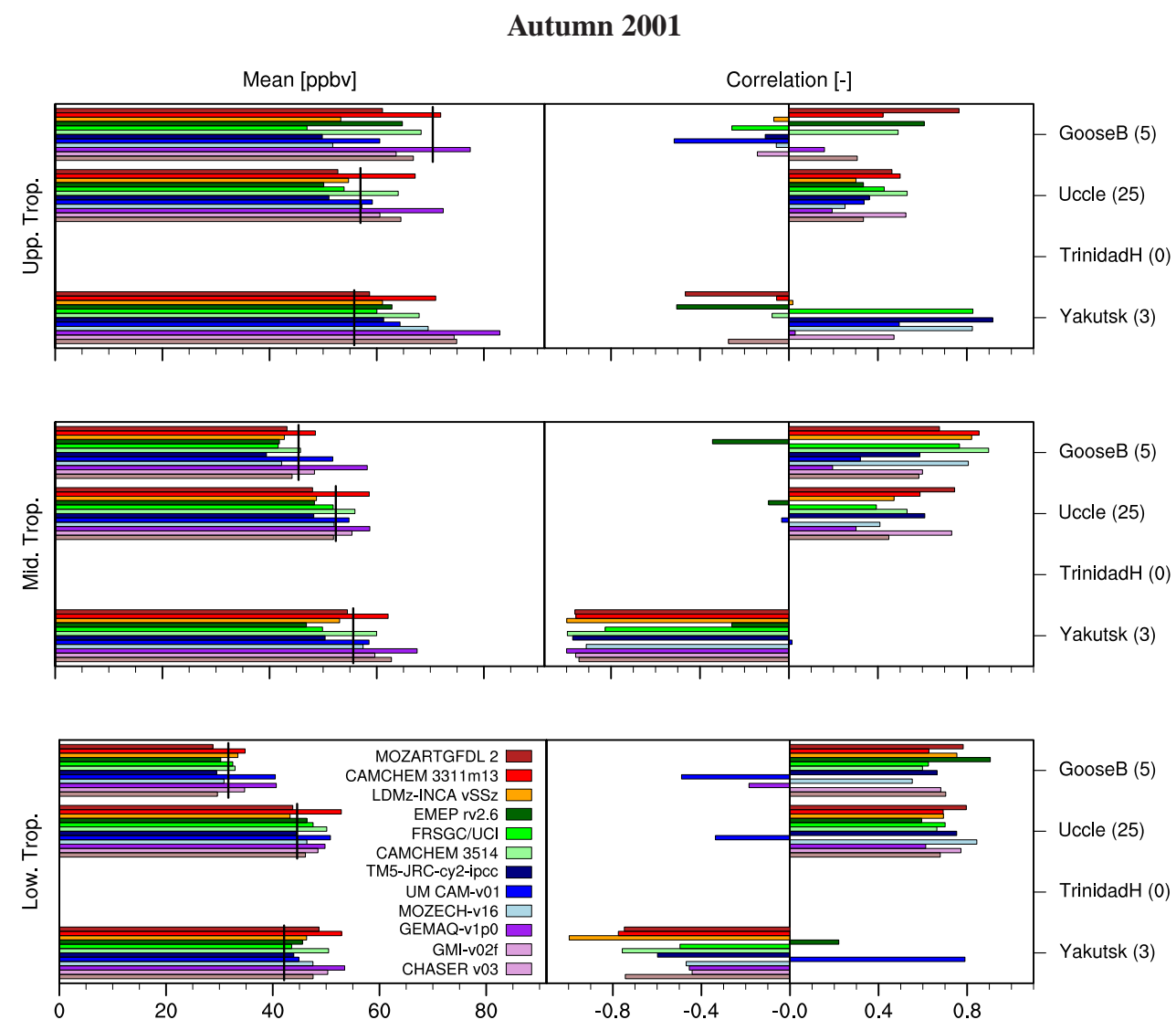

Fig. 6. Measured and model-calculated ozone (ppb) in autumn (September, October, November) for the lower troposphere (900-700 hPa), middle troposphere (700-500 hPa) and upper troposphere (500-300 hPa) for the selected ozonesonde sites. Concentrations to the left (solid lines crossing the model calculations are measurements), correlations to the right. The numbers behind the site name refer to the number of soundings available for comparison in the Autumn. GooseB. is short for Goose Bay, TrinidadH is short for Trinidad Head.

resolved in global models, and this could partially explain the somewhat lower model to sonde correlation in the lower troposphere. In the upper troposphere there is a tendency for many models to overpredict ozone levels in the winter and underpredict in spring.

\subsubsection{Goose Bay: tracing plumes within the North American continent}

This site is located at $53.32^{\circ} \mathrm{N}$ and $60.13^{\circ} \mathrm{W}$. Even though this site is within the NA region as defined in Sect. 3 it is well outside major US and Canadian source regions, but as also shown in Sect. 4.2, these sources contribute significantly to ozone levels above this site. As such this site is well suited for identifying transport events within the North American continent. 13 June 2001 has been selected as an example of advection to this site. In Fig. 12a the model-calculated vertical profiles are compared to the ozone sounding. The ozone soundings and most of the models show high ozone levels in the lower troposphere for this date. Furthermore, in Fig. 12b the models show reductions of the order of 2-
$5.5 \mathrm{ppb}$ in the lower troposphere from $20 \%$ reductions in NA emissions (SR20\%NA scenario, as defined in Sect. 3). The model range in calculated ozone and the ozonesondes are shown in the right section of Fig. 7 for the lower, middle and upper troposphere for a two week period centred around 13 June. For the same height intervals the model range in the contributions from domestic and transcontinental regions is also shown. At this site the dominant calculated contributions to ozone at all levels are from the domestic NA region throughout this period.

Also for 13 June, Fig. 16a shows the age spectrum for CO for the past 20 days as calculated by the FLEXPART model above Goose Bay. The calculated enhancement of $\mathrm{CO}$ in the lower troposphere is seen to be caused by emissions over the past 2-5 days. The footprint emission sensitivity for Goose Bay for the lower part of the troposphere (release height 0 $250 \mathrm{~m}$ ) at 12:00 UTC 13 June (Fig. 12c) indicates that the sources of these $\mathrm{CO}$ emissions, corresponding to the excess ozone in the lower troposphere in Fig. 12b, can be traced to emissions at the US east coast and around the Great Lakes a few days earlier. Figures $12 \mathrm{~d}$ and e show the difference in 


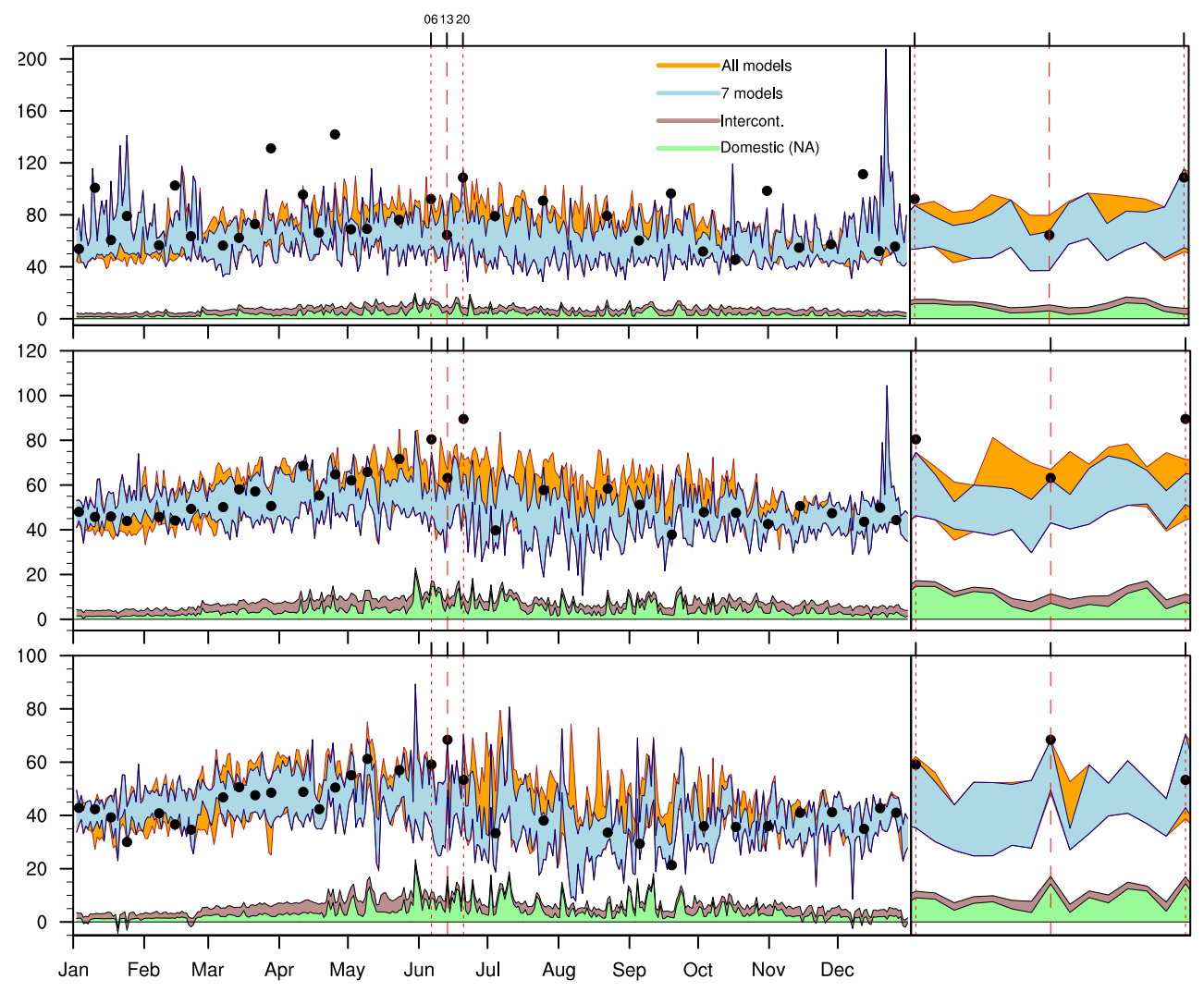

Fig. 7. Daily range of noon ozone levels in ppb and stacked from intercontinental (EU, EA and SA) and domestic (NA) contributions for Goose Bay in the UT (500-300 hPa) top, MT (700-500 hPa) middle and LT (900-700 hPa) bottom panel. The focused panels on the right hand side are centred around the 13 June. episode, highlighted in Section 4.1.1 and bounded by red lines in the figure. The range for the first seven models listed in Table 1 are shown in blue. The additional range, including all models in Table 1, are shown in orange. Ozone measurements from ozonesondes are marked as black dots. The model mean stacked contributions (multipl. by 5) from domestic (NA) and intercontinental (EU, EA and SA) are also shown.

calculated daily maximum ozone at the surface and the difference in total ozone column in the troposphere respectively, between SRref and SR20\%NA calculated with the EMEP model. It shows only small changes in maximum ozone levels directly above Goose Bay, but marked enhancements of the tropospheric column that can be attributed to changes in the lower troposphere.

\subsubsection{Uccle: tracing trans Atlantic advection}

Uccle is located at $50.48^{\circ} \mathrm{N}$ and $4.21^{\circ} \mathrm{E}$ in Belgium, in the western part of Europe. As discussed in Sect. 4.2 the largest calculated contribution in the middle and upper troposphere is from the NA region. As an example of advection to this site we have selected 1 June as there are ozone soundings for this date (Fig. 13a). Except for one model, the ozonesonde measurements are rather well reproduced by the numerical simulations, but the elevated ozone in the upper troposphere is not fully accounted for by the models. All models do however show a $1 \mathrm{ppb}$ or more contribution from a $20 \%$ reduction in North American emissions (Fig. 13b) in the mid and up- per troposphere suggesting that this excess ozone could be of North American origin. The model range in calculated ozone and the ozonesondes are shown in the right hand part of Figure 8 for the lower, middle and upper troposphere for a two week period centred around 1 June. For the same height intervals we show the model range in the contributions from domestic and transcontinental regions. At this site the main contributions to ozone at all height intervals are transcontinental (mainly from the NA region) throughout this period, with the largest contributions around 1 June.

Figure $16 \mathrm{~b}$ shows the age spectrum also from 1 June for $\mathrm{CO}$ calculated based on emissions for the past 20 days as calculated by the FLEXPART model above Uccle. The large calculated enhancement of $\mathrm{CO}$ in the lower troposphere is thought to be caused by emissions over the past 1-2 days and should be attributed to local European emissions. $\mathrm{CO}$ enhancements in the middle and upper troposphere are however attributed to emissions several days earlier. Figure 13c shows the footprint emission sensitivity for retroplumes released in the middle troposphere, between 5250 and $5500 \mathrm{~m}$. At this level the retroplumes indicate that the $\mathrm{CO}$ enhancement also 


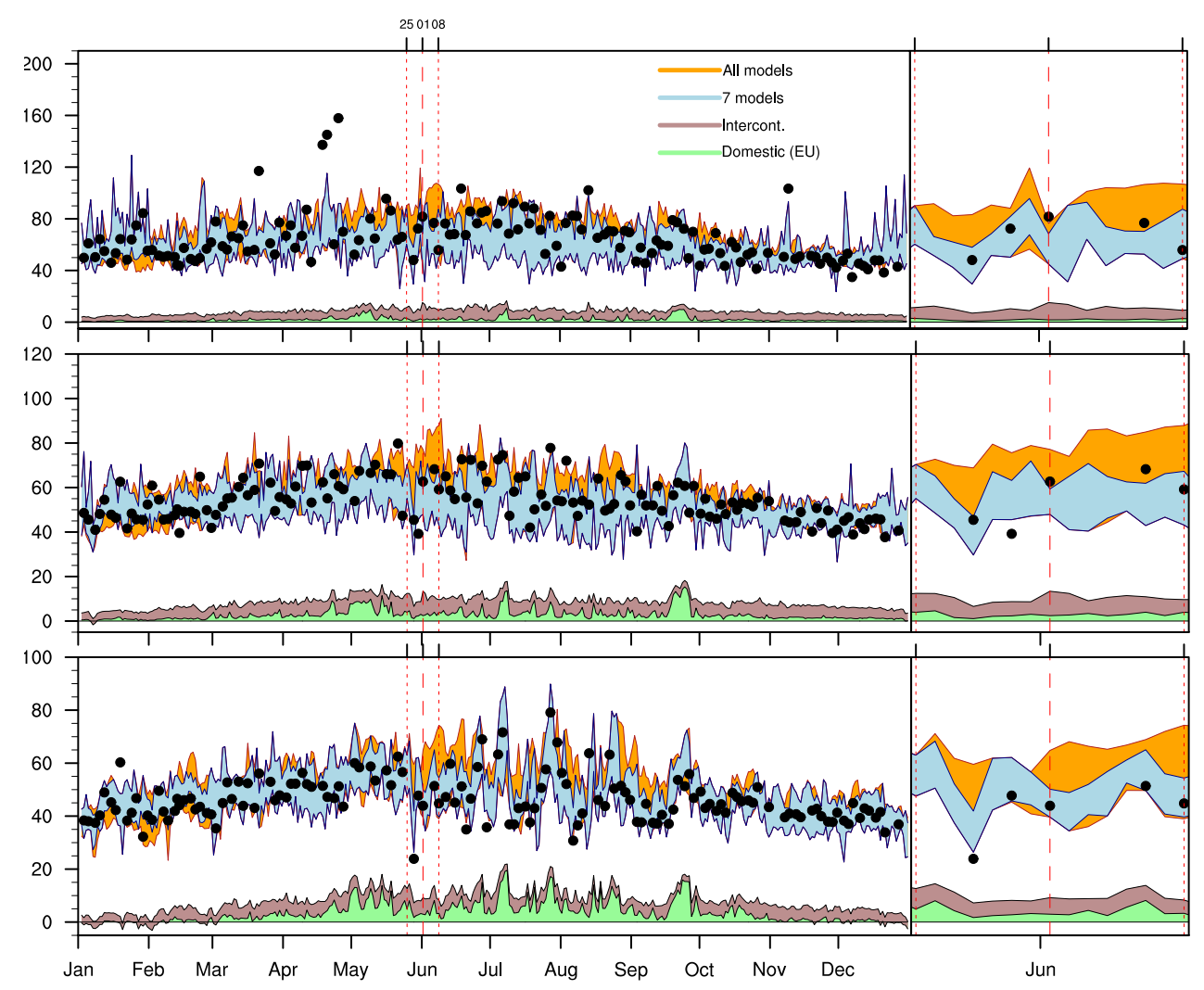

Fig. 8. Daily range of calculated ozone and stacked intercontinental (NA, EA and SA) and domestic (EU) contributions from at Uccle in the UT (500-300 hPa) top, MT (700-500 hPa) middle and LT (900-700 hPa) bottom panel. The focused panels on the right hand side are centred around the 1 June episode, highlighted in Section 4.1.2 and bounded by red lines in the figure. The range for the first seven models listed in Table 1 are shown in blue. The additional range, including all models in Table 1, are shown in orange. Ozone measurements from ozonesondes are marked as black dots. The model mean stacked contributions (multipl. by 5) from domestic (EU) and intercontinental (NA, EA and SA) are also shown.

seen in Fig. 16b in the middle and upper troposphere should be attributed to emissions from the North American continent, as also seen in Fig. 13b.

Figure $13 \mathrm{~d}$ and $13 \mathrm{e}$ show the difference between the reference run SRref and SR20\%NA in daily maximum surfaceozone and total tropospheric ozone column calculated by the EMEP Unified model for noon, 1 June. At the surface there is virtually no contribution from North America to the daily maximum ozone, as also shown in Fig. 13b for all the models. For the tropospheric ozone column there is a marked difference attributed to contributions from North America extending to western Europe.

\subsubsection{Trinidad Head: tracing trans Pacific advection of ozone}

Trinidad Head is located at $41.05^{\circ} \mathrm{N}$ and $124.15^{\circ} \mathrm{W}$, at the west coast of North America. Section 4.2 shows that the largest calculated contribution to ozone in the middle and upper troposphere originates from the EA region at this site, making this location well suited for detecting trans Pacific pollution events. Transport events of air pollutants from Asia to the western parts of North America typically occur 12 times per month, predominantly in the middle and upper free troposphere (Liang et al., 2004). As an example of such events, 23 April has been selected. Unfortunately no ozone sounding was available for this particular date. As is typical for spring and summer conditions, the spread in modelcalculated ozone profiles is relatively large (Fig. 14a). The model-calculated difference in the vertical ozone profiles between the reference model run and the model runs with reduced emissions in East Asia (SR20\%EA) is somewhat less than $1 \mathrm{ppb}$ throughout the troposphere for all models except one (Fig. 14b). The model range in calculated ozone and the ozonesondes are shown in the right hand part of Figure 9 for the lower, middle and upper troposphere for a two week period centred around 23 April. For the same height intervals the model range in domestic and transcontinental contributions to ozone is also shown. At this site the main calculated contributions to ozone at all height intervals are transcontinental (mainly from the EA region) throughout this period. 


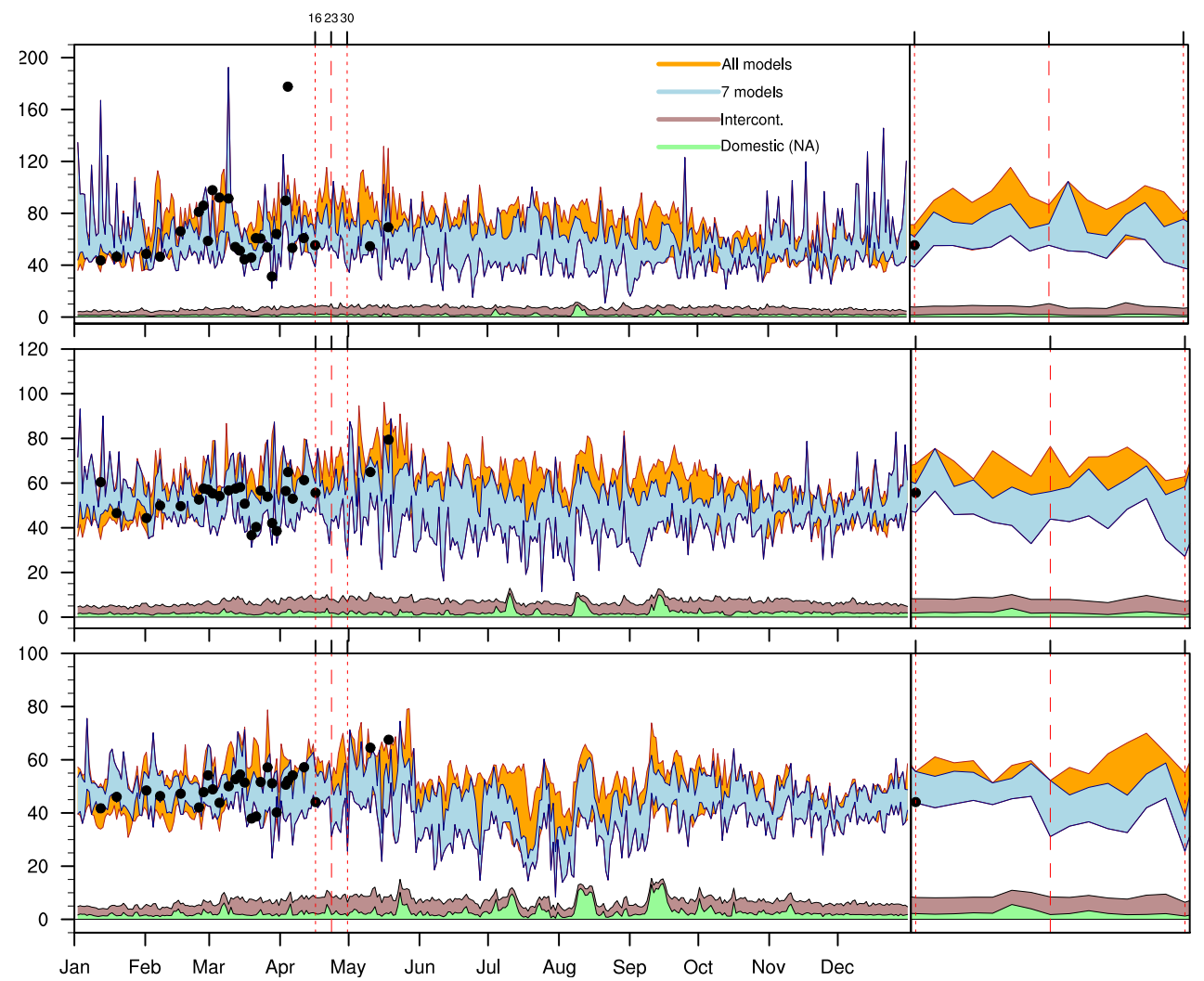

Fig. 9. Daily range of calculated ozone and stacked intercontinental (EU, EA and SA) and domestic (NA) contributions at Trinidad Head in the UT (500-300 hPa) top, MT (700-500 hPa) middle and LT (900-700 hPa) bottom panel. The focused panels on the right hand side are centred around the 23 April. episode, highlighted in Sect. 4.1.3 and bounded by red lines in the figure. The range for the first seven models listed in Table 1 are shown in blue. The additional range, including all models in Table 1, are shown in orange. Ozone measurements from ozonesondes are marked as black dots. The model mean stacked contributions (multipl. by 5) from domestic (NA) and intercontinental (EU, EA and SA) are also shown.

Figure 16c shows the age spectrum for $\mathrm{CO}$ for the past 20 days as calculated by the FLEXPART model above Trinidad Head for 13 June. Large calculated enhancements of $\mathrm{CO}$ are calculated for the middle and in particular the upper troposphere. The enhancements are to a large extent caused by emissions more than a week old. The footprint emission sensitivity for Trinidad Head at 12:00 UTC 13 June (Fig. 14c) with retroplumes released in the upper troposphere confirms that the enhancements are caused by East Asian emissions, but the FLEXPART calculations differ from the global models in the sense that the Asian influence is even more concentrated to the upper troposphere.

The difference in daily maximum surface ozone calculated with the EMEP model between SRref and the model run reducing all emission in East Asia by $20 \%$ are shown in Fig. 14d). The effects on daily maximum ozone is of the order of $0.5 \mathrm{ppb}$ throughout much of the Pacific, with a tongue of excess ozone of 2-3 ppb just west of the North American continent. This tongue is seen throughout the tropospheric column (Fig. 14e) covering also parts of the North American continent.

\subsubsection{Yakutsk: tracing trans Eurasian emissions}

Yakutsk is located at $62.01^{\circ} \mathrm{N} 129.75^{\circ} \mathrm{E}$, in the Siberian part of Russia. This site was selected for tracing plumes from Europe across the Eurasian continent. As discussed in the introduction, ozone from the EU region is primarily advected in the lower atmosphere where the lifetime is markedly shorter than in the free troposphere. It is therefore difficult to identify specific transport events from EU to this site. As an example of ozone reaching this site, May 9 was chosen, as all the models calculated a significant contribution from the EU region based on the difference in vertical ozone profiles. In the free troposphere all models calculate an approximately $1 \mathrm{ppb}$ difference between SRref and SR20\%EU, reducing all emissions in the European region (Fig. 15b). Unfortunately no ozone sounding is available for this date at Yakutsk. Vertical profiles calculated by the models are shown in Fig. 15a. The model range in calculated ozone and the ozonesondes are shown in the right hand part of Fig. 10 for the lower, middle and upper troposphere for a two week period centred around 9 May. For the same height intervals the model 


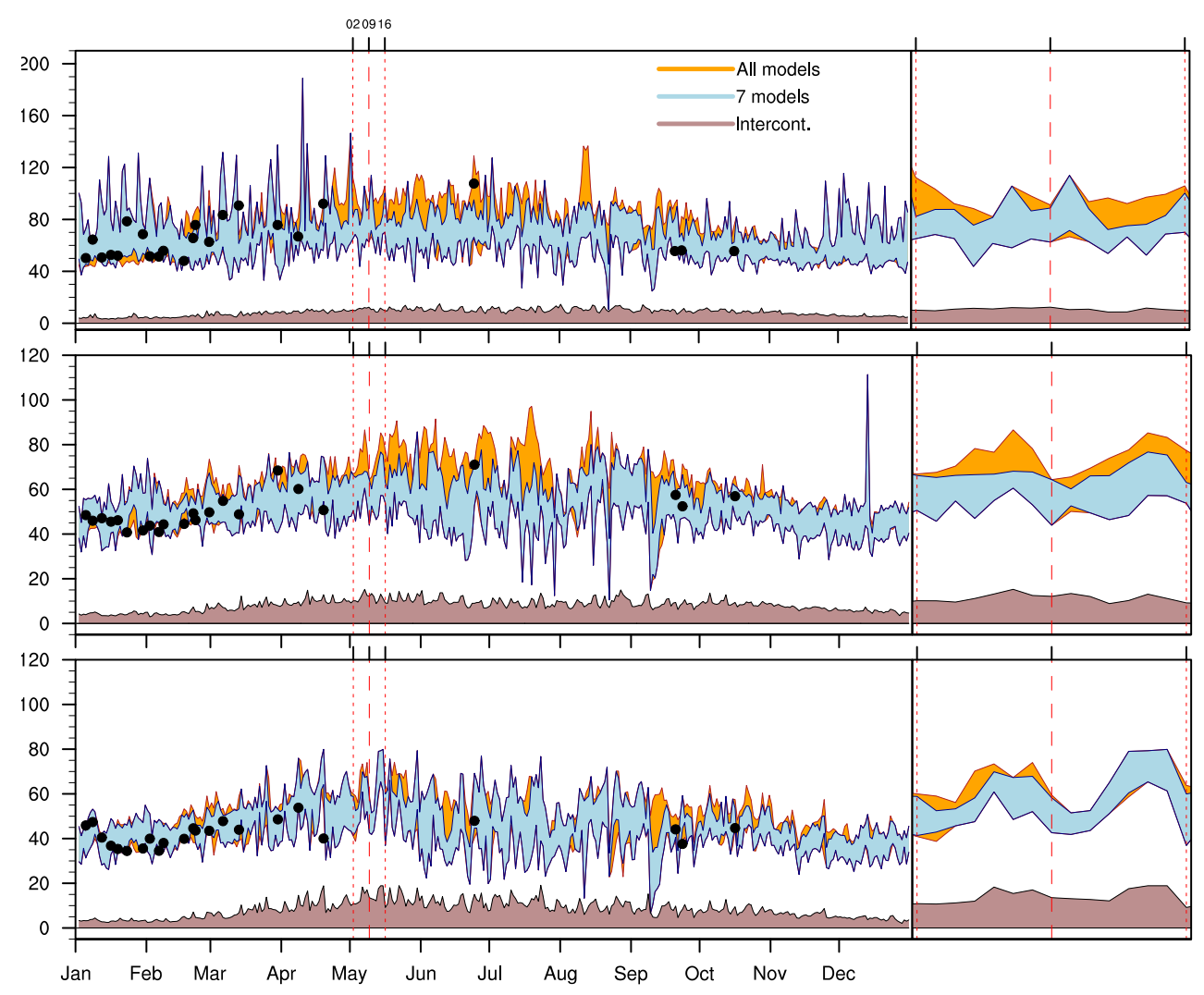

Fig. 10. Daily range of calculated ozone and stacked intercontinental (NA, EU, EA and SA) contributions at Yakutsk in the UT (500$300 \mathrm{hPa})$ top, MT (700-500 hPa) middle and LT $(900-700 \mathrm{hPa})$ bottom panel. The focused panels on the right hand side are centred around the 9 May. episode, highlighted in Sect. 4.1.4 and bounded by red lines in the figure. The range for the first seven models listed in Table 1 are shown in blue. The additional range, including all models in Table 1, are shown in orange. Ozone measurements from ozonesondes are marked as black dots. The model mean stacked contributions (multipl. by 5) from intercontinental (all regions, NA, EU, EA and SA) are also shown.

range in the transcontinental contributions to ozone is also shown. As this site is outside all of the regions specified in Sect. 3 there are no calculated domestic contributions, and all the calculated contributions are transcontinental. Throughout the two week period the largest calculated contributions to ozone are from the EA region, in particular in the lower troposphere, but there are also variable contributions from the EU region.

Figure 16d shows the age spectrum for $\mathrm{CO}$ for the past 20 days as calculated by the FLEXPART model above Yakutsk for 9 May. Moderate calculated enhancements of $\mathrm{CO}$ are calculated for the middle and lower troposphere. The enhancements are to a large extent caused by emissions more than 1-2 weeks old. Footprint emission sensitivity retroplumes with release height between $3500-3750 \mathrm{~m}$ are shown in Fig. 15c). A substantial fraction of the air can be traced back to the Scandinavian countries. The potential for forming ozone from this region is small due to low emissions of ozone precursors and low insolation. There is also relatively high emission sensitivity over central parts of Europe, where emissions of ozone precursors are higher. The difference in daily maximum ozone between SRref and SR20\%EU calculated with the EMEP model for May 9 (Fig. 15d) is typically about $0.5 \mathrm{ppb}$ in large parts of Asia, with signs of plumes of more than $1 \mathrm{ppb}$ advected in the boundary layer further west and south. For the tropospheric ozone column the difference plot between SRref and SR20\%EU (Fig. 15e) show plumes advected in the vicinity of Yakutsk.

\subsection{Intercontinental transport}

In Fig. 17 to 20 the seasonal contributions to ozone from $20 \%$ reductions in the emissions in the four source regions are shown for the same sonde sites as in Figs. 3 to 6 based on the daily vertical profiles from seven numerical models at noon. In addition the daily model ensemble contributions are shown in Figs. 7 to 10. Daily model ensemble and for additional sites are also shown in the supplement material. As in Figs. 3 to 6 , the data are separated into the lower, middle and upper troposphere. The calculated transcontinental contributions from 20\% reductions in emissions shown in Figs. 17 to 20 are often in the $0.5-1 \mathrm{ppb}$ range, with contributions for 


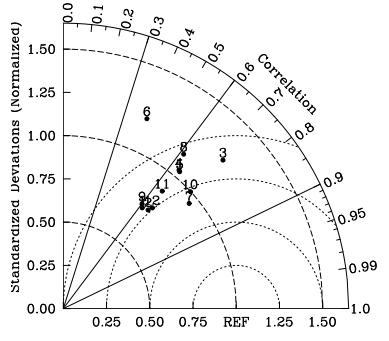

a) Uccle, lower trop.

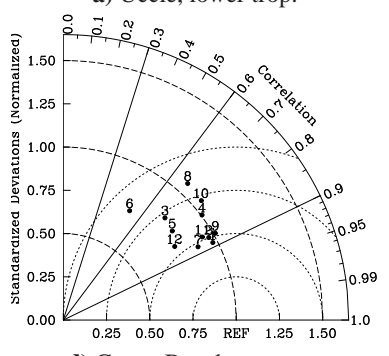

d) Goose Bay, lower trop.

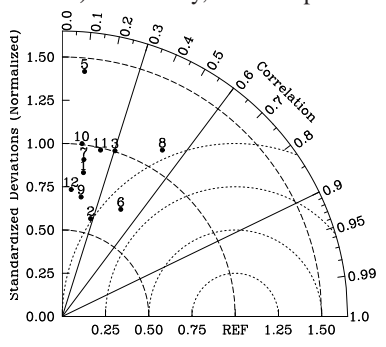

g) Trinidad Head, lower trop.

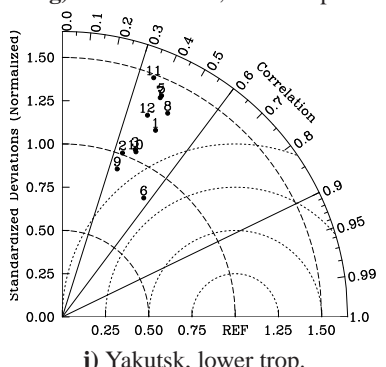

j) Yakutsk, lower trop.

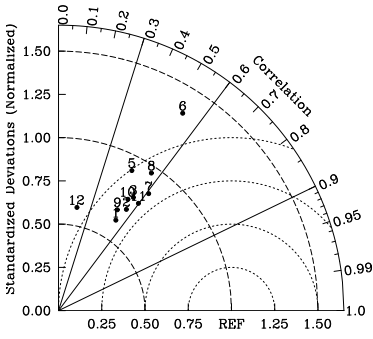

b) Uccle, middle trop.

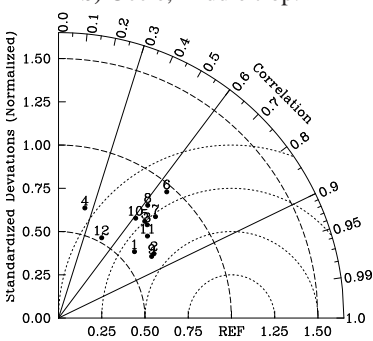

e) Goose Bay, middle trop

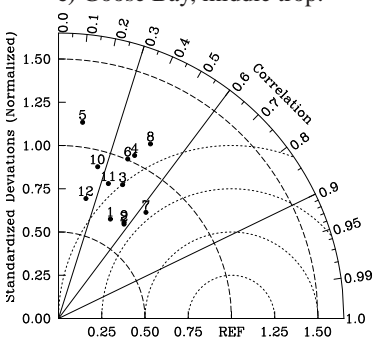

h) Trinidad Head, middle trop.

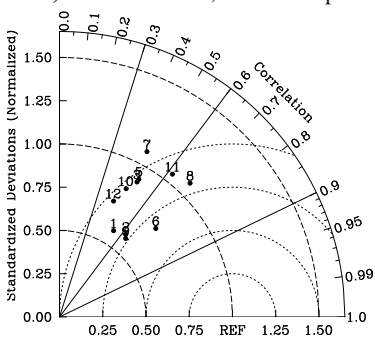

k) Yakutsk, middle trop.

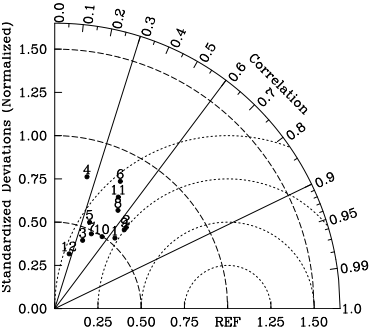

c) Uccle, upper trop.

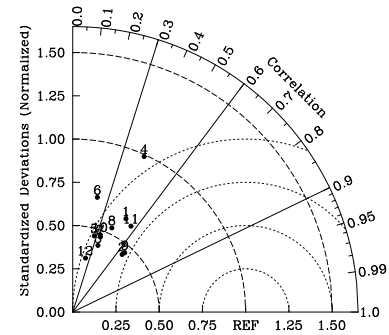

f) Goose Bay, upper trop.

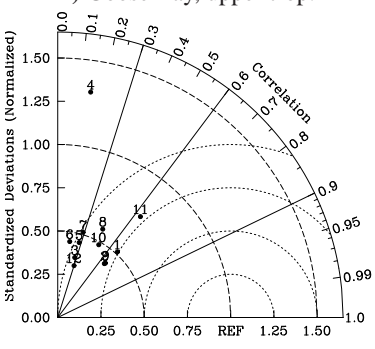

i) Trinidad Head, upper trop.

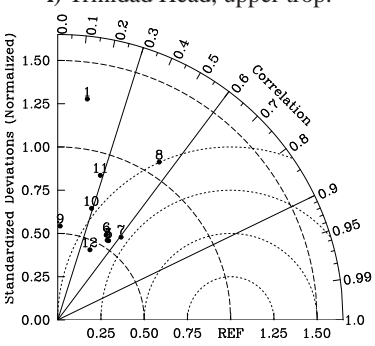

l) Yakutsk, upper trop.

Fig. 11. Taylor diagrams showing correlations, normalised standard deviations (proportional to the radial distance from the origin) and RMS errors (proportional to the point on the x-axis identified as "REF") for the comparison of ozone soundings and calculated vertical profiles for the 12 models listed in Table 1.

some sites and models well above $1 \mathrm{ppb}$. The seasonality of the transcontinental (or foreign) contributions in the free troposphere differ between the sites, but for all sites and models the contributions are small in winter.

The transcontinental contributions are episodic in their nature, and care should be taken as the data are based on one year only.

Several of the sonde sites, Goose Bay and Trinidad Head (and Huntsville and Edmonton in the supplement material), are located in the NA region. The magnitude of the model mean foreign impact (from EA, SA and EU) differs between the sites. At Trinidad Head the model mean foreign impact is highest in spring, adding up to about $1 \mathrm{ppb}$ or more at all levels. In the upper and mid troposphere the foreign impact is only slightly reduced in summer. Above Goose Bay (and Huntsville) the foreign impact is always lower and about $0.8 \mathrm{ppb}$ in spring. Contrary to Trinidad Head the foreign impact is markedly lower in summer. The higher foreign impact at Trinidad Head is mainly caused by larger contributions from the EA region. At Edmonton (see supplementary material) the domestic contribution is small due to its position well north of the main source areas in the NA region, but calculated intercontinental contributions (mainly from EA) are similar or higher than at Trinidad Head. As can be expected the foreign impact in the free troposphere is higher than what was calculated for NA at the surface in Fiore et al. 


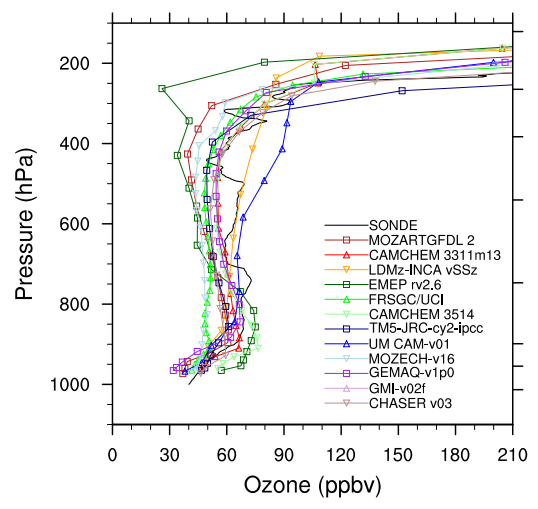

a) Goose Bay June 13

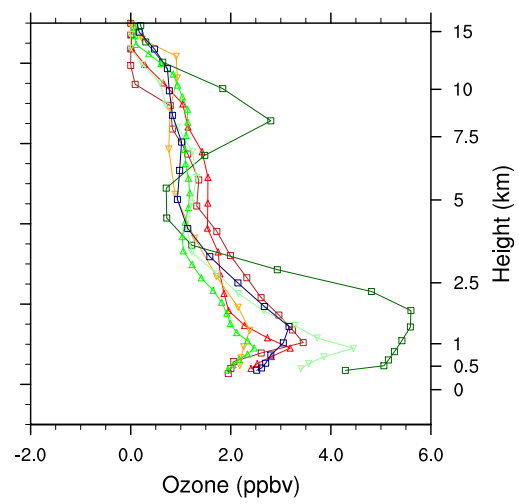

b) Goose Bay June 13 (from NA)

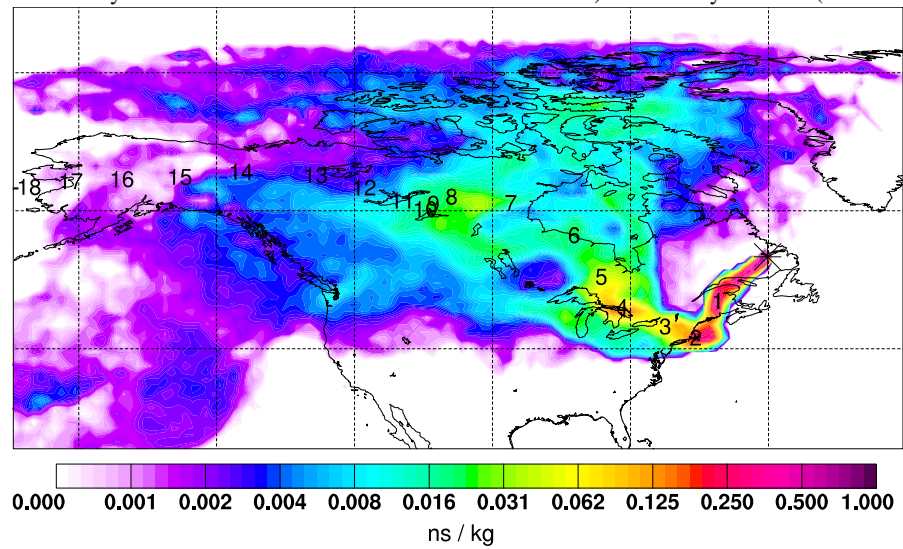

c) Footprint emission sensitivity, Goose Bay. Release height $0-250 \mathrm{~m}$

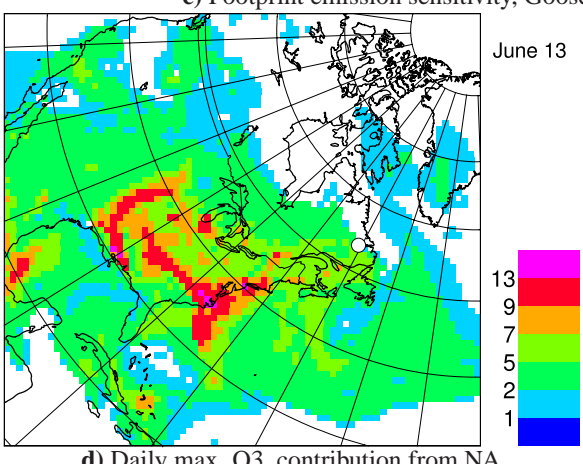

d) Daily max. O3, contribution from NA

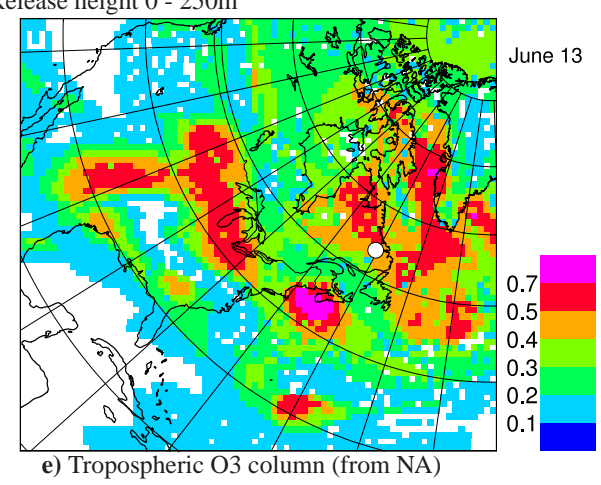

Fig. 12. All panels for 13 June, 12:00 UTC. (a) Ozone sounding and calculated vertical profiles for the 12 models listed in Table 1 in ppb. (b) Calculated difference SRref - SR20\%NA in ppb for the 7 models, showing the effect of a $20 \%$ reduction of North American emissions. (c) FLEXPART footprint emission sensitivity for Goose Bay for the 0-250 m layer in ns $/ \mathrm{kg}$ (nanoseconds/kg). The asterisk marks the position of the ozonesonde site. (d) Difference (SRref - SR20\%NA) in daily maximum surface-ozone in ppb calculated with the EMEP model. (e) Difference (SRref - SR20\%NA) in tropospheric ozone column (DU) calculated with the EMEP model. White circle marks the position of Goose Bay in (d) and (e).

(2009). Within the United states Reidmiller et al. (2009) found the largest foreign impact in the Western United States in spring with about $0.9 \mathrm{ppb}$. During summer the foreign impact fell to about 0.5 here. In the Eastern United States the calculated foreign impact was about half that of the Western United states. Our results are in good agreement with Holzer et al. (2005) where they found that the surface signal of East Asian sources is strongest in spring, and that East
Asian air is transported aloft in summer. In a general eastward circulation, air exposed to loss processes in the boundary layer is mixed into the free troposphere through increased venting over the continent in the summer, reducing the foreign contribution to ozone also in the free troposphere. As a result sites at the eastern side of the continent (Goose Bay and Huntsville) have a summer minimum in foreign ozone throughout the tropospheric column, whereas sites located at 


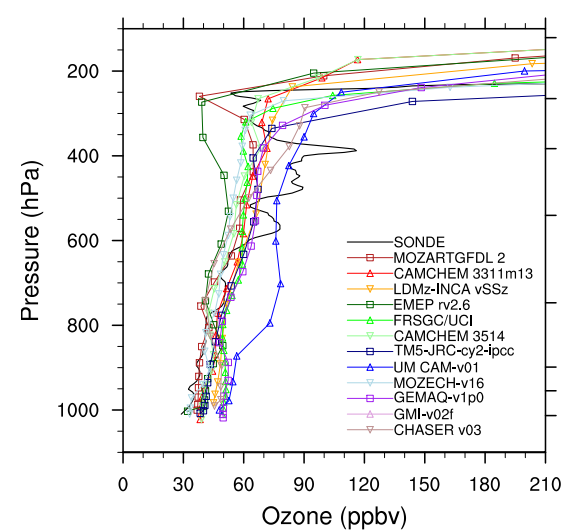

a) Uccle June 1

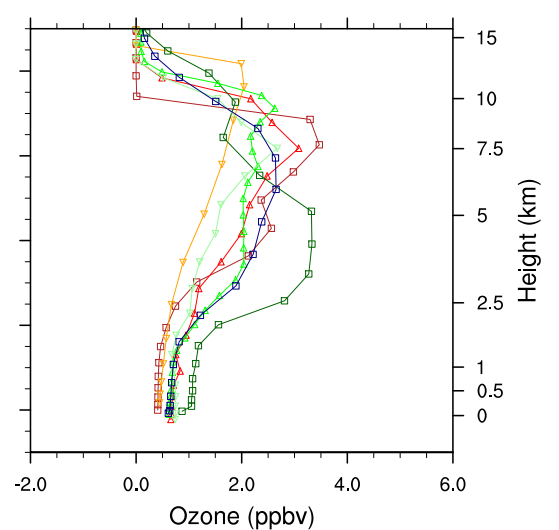

b) Uccle June 1 (from NA)

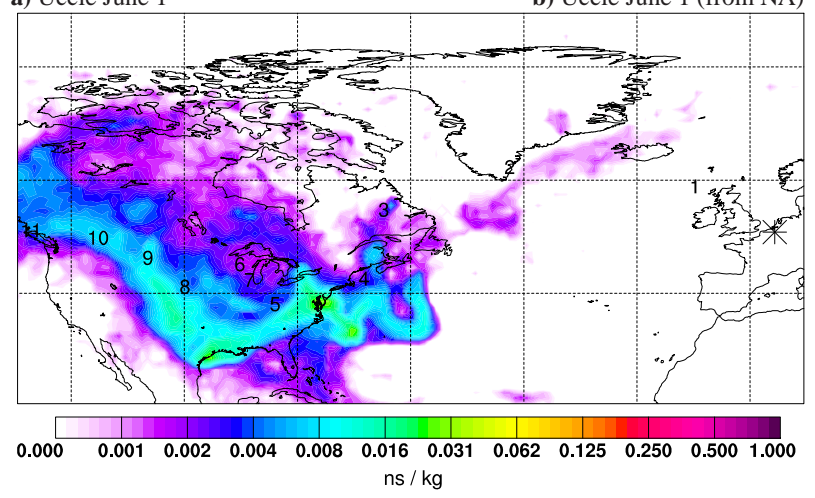

c) Footprint emission sensitivity, Uccle. Release height 5250 - 5500m

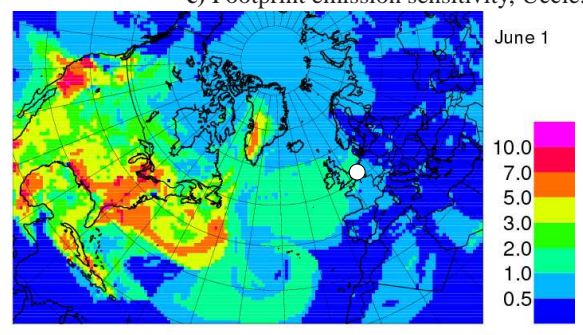

d) Daily max. O3, contribution from NA.

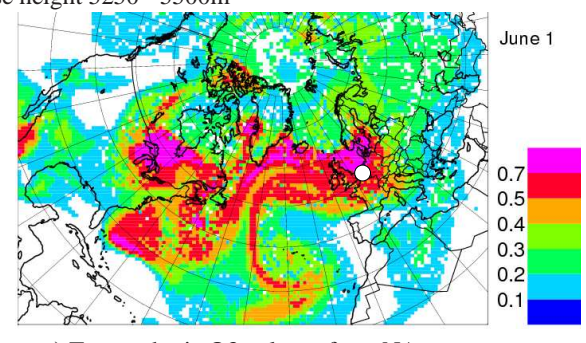

e) Tropospheric O3 column from NA.

Fig. 13. All panels for 1 June, 12:00 UTC. (a) Ozone sounding and calculated vertical profiles in ppb for the 12 models listed in Table 1. (b) Calculated difference SRref - SR20\%NA in ppb for the 7 models, showing the effect of a 20\% reduction of North American emissions. (c) Footprint emission sensitivity (release height $5250-5500 \mathrm{~m}$ ) from Uccle in ns $/ \mathrm{kg}$ (nanoseconds/kg). The asterisk marks the position of the ozonesonde site. (d) Difference (SRref - SR20\%NA) in daily maximum surface-ozone in ppb calculated with the EMEP model. (e) Difference (SRref - SR20\%NA) in tropospheric ozone column (DU) calculated with the EMEP model. White circle marks the position of Uccle in (d) and (e).

the western side of the US continent (as Trinidad Head and Edmonton) will have a marked summer minimum in the foreign impact only near the surface.

At Uccle, in the western part of Europe, the calculated transcontinental contributions in the middle and upper troposphere are larger than the domestic contributions (up to about $1 \mathrm{ppb}$ or more at all levels with NA as the largest single source). In the lower troposphere the largest contributions are from domestic sources in most of the year. Positioned east of major EU source areas the contributions from domestic sources are even larger at Payerne and Hohenpeissenberg (see supplementary material) in the lower troposphere. Even so, these two sites are relatively close to Uccle (in particular compared to the distance between Trinidad Head and Huntsville/Goose Bay in NA), and intercontinental contributions are comparable for the three sites Uccle, Payerne and Hohenpeissenberg. The larger contribution in the free troposphere compared to what was calculated as foreign impact to EU at the surface in Fiore et al. (2009) can partially be explained by the sites being located close to the windward margin of the EU domain, and partially because of higher transcontinental contributions in the free troposphere. 


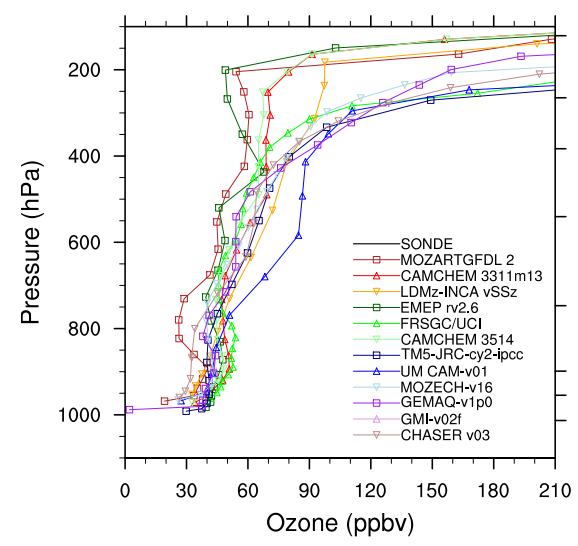

a) Trinidad Head April 23

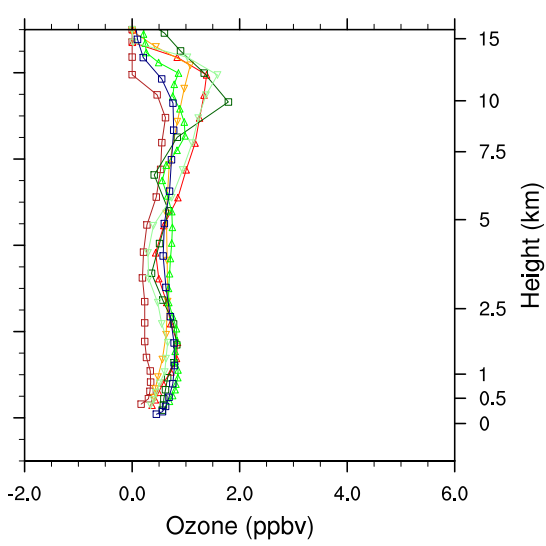

b) Trinidad Head April 23 (from EA)

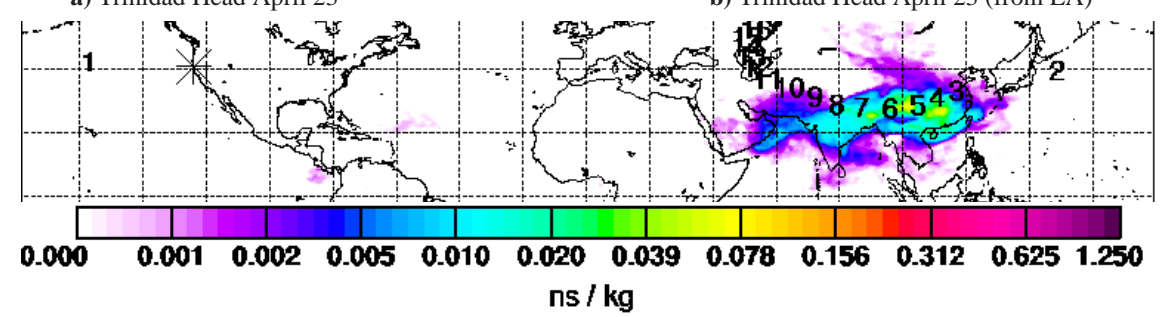

c) Footprint emission sensitivity, Trinidad Head. Release height 10750 - 11000m

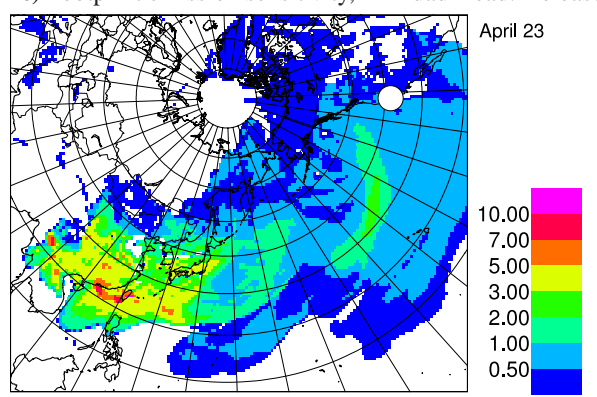

d) Daily max. O3, contribution from EA

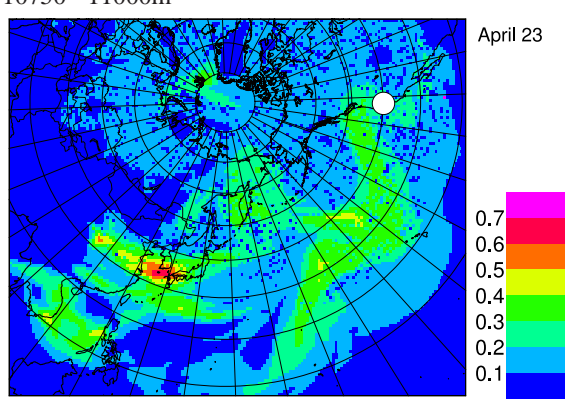

e) Tropospheric O3 column (from EA)

Fig. 14. All panels for 23 April, 12:00 UTC. (a) Ozone sounding and calculated vertical profiles in ppb for the 12 models listed in Table 1 . (b) Calculated difference SRref - SR20\%EA in ppb for the 7 models, showing the effect of a 20\% reduction of East Asian emissions. (c) Footprint emission sensitivity (release height $10750-1100 \mathrm{~m}$ ) from Trinidad Head in ns $/ \mathrm{kg}$ (nanoseconds/kg). The asterisk marks the position of the ozonesonde site. (d) Difference (SRref - SR20\%EA) in daily maximum surface-ozone in ppb calculated with the EMEP model. (e) Difference (SRref - SR20\%EA) in tropospheric ozone column (DU) calculated with the EMEP model. White circle marks the position of Trinidad Head in (d) and (e).

A higher foreign contribution in the free troposphere is in good agreement with Auvray and Bey (2005). They found a maximum in ozone from North America in Spring and summer. As a result of deep convection in summer they found a high contribution from North American ozone at high altitudes. The low level advection of ozone across the North Atlantic was found to be important only in spring, when loss rates in the boundary layer are weaker.

In winter the advection to Yakutsk is dominated by the Siberian high, with airmasses crossing the Eurasian continent, potentially advecting pollution of European origin to Yakutsk. But in the winter months the chemical activity is very low resulting in low contributions to ozone levels above
Yakutsk from all the four source regions. From Europe a major part of the pollutants are advected in the boundary layer or lower troposphere where the lifetime of ozone is short. Following the breakdown of the Siberian high in Spring, the foreign impacts calculated above Yakutsk, of the order of 2ppb, are the highest among all the sites. The largest contributions at Yakutsk are now from EA at all levels. At Yakutsk all the four source regions considered here are foreign, and this could partially explain the higher intercontinental contribution here. The attribution of sources to Yakutsk differs from that of Mondy described in Wild et al. (2004) as it seems to receive less pollution from Europe. Yakutsk is located about $20^{\circ}$ further east, and it receives a much large portion 

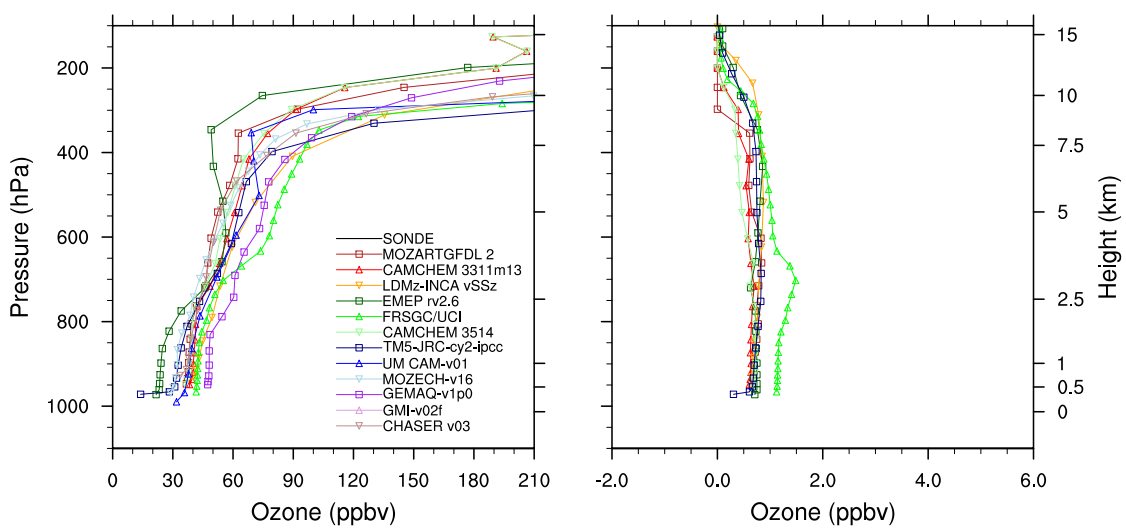

a) Yakutsk May 9

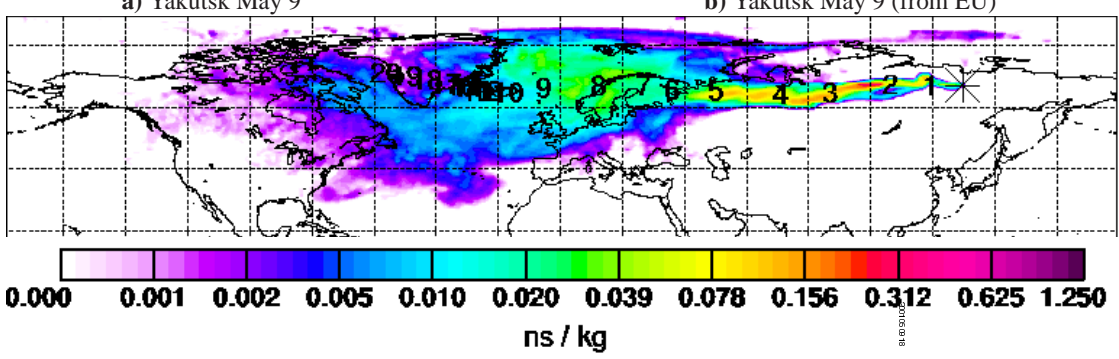

c) Footprint emission sensitivity, Yakutsk Release height 3500 - 3750m

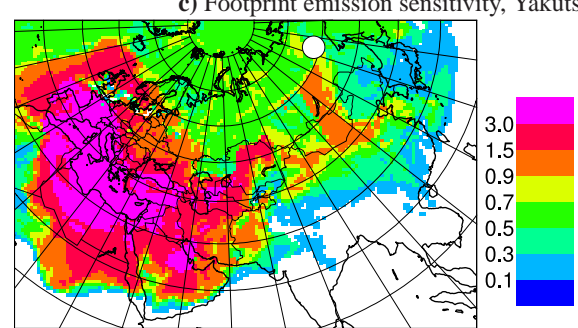

d) Daily max. O3, contribution from EU

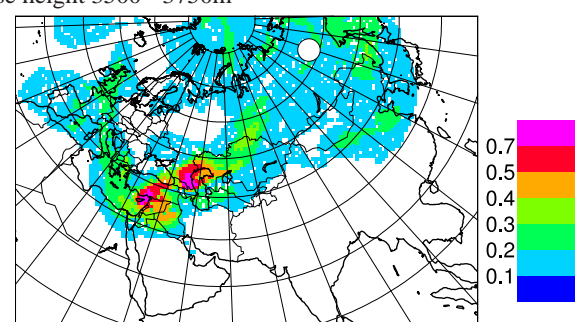

e) Tropospheric $\mathrm{O} 3$ column (from EU)

Fig. 15. All panels for 9 May, 12:00 UTC. (a) Ozone sounding and calculated vertical profiles in ppb for the 12 models listed in Table 1 . (b) Calculated difference SRref - SR20\%EU in ppb for the 7 models, showing the effect of a $20 \%$ reduction of European emissions. (c) Footprint emission sensitivity (release height $0-250 \mathrm{~m}$ ) from Yakutsk. in ns $/ \mathrm{kg}$ (nanoseconds $/ \mathrm{kg}$ ). The asterisk marks the position of the ozonesonde site. (d) Difference (SRref - SR20\%EU) in daily maximum surface-ozone in ppb calculated with the EMEP model. (e) Difference (SRref SR20\%EU) in tropospheric ozone column (DU) calculated with the EMEP model. White circle marks the position of Yakutsk in (d) and (e).

of its pollution from EA, and as a result this site is less ideal for identifying pollutant transport from Europe. Paris et al. (2008) also found that advection of boundary layer air exposed to Asian emissions and lifted by Warm Conveyor Belt contributed significantly to $\mathrm{CO}$ and $\mathrm{CO}_{2}$ enhancements in the upper troposphere in Siberia during the YAK-AEROSIB aircraft campaigns in April 2006.

Ozone at Tateno and Taipei (supplementary material) are affected by large local sources, but also by sources at the East Asian mainland. The calculated contribution from intercontinental transport is small above Taipei. However, further northeast, above Tateno there are marked contributions from EU, and partially NA emissions.

The two polar sites Alert and Ny Ålesund are both located well outside the four source regions. At Alert calculated contributions from NA and EU are about equal in magnitude, but with marked contributions also from EA. At Ny Ålesund about two thirds of the contributions are from EU and one third from NA. Calculated contributions from EA are small.

The contributions from transcontinental pollution for individual episodes shown in Figs. 12b-15b gives an impression of a better agreement between the models than Figs. 17 to 20 . The episodes presented in Figs. 12b-15b are however chosen because of particular strong signals in the contributions from selected regions and illustrates that the models have predictability on a hemispheric scale for such events. The episodes chosen showing transcontinental contributions to Uccle (Sect. 4.1.2), Trinidad Head (Sect. 4.1.3) and Yakutsk (Sect. 4.1.4) illustrates typical mechanisms for these events. Trans Atlantic advection to Uccle and trans Pacific advection to Trinidad Head are resulting from lifting near the east coast of the source continent and subsequent advection in the free 


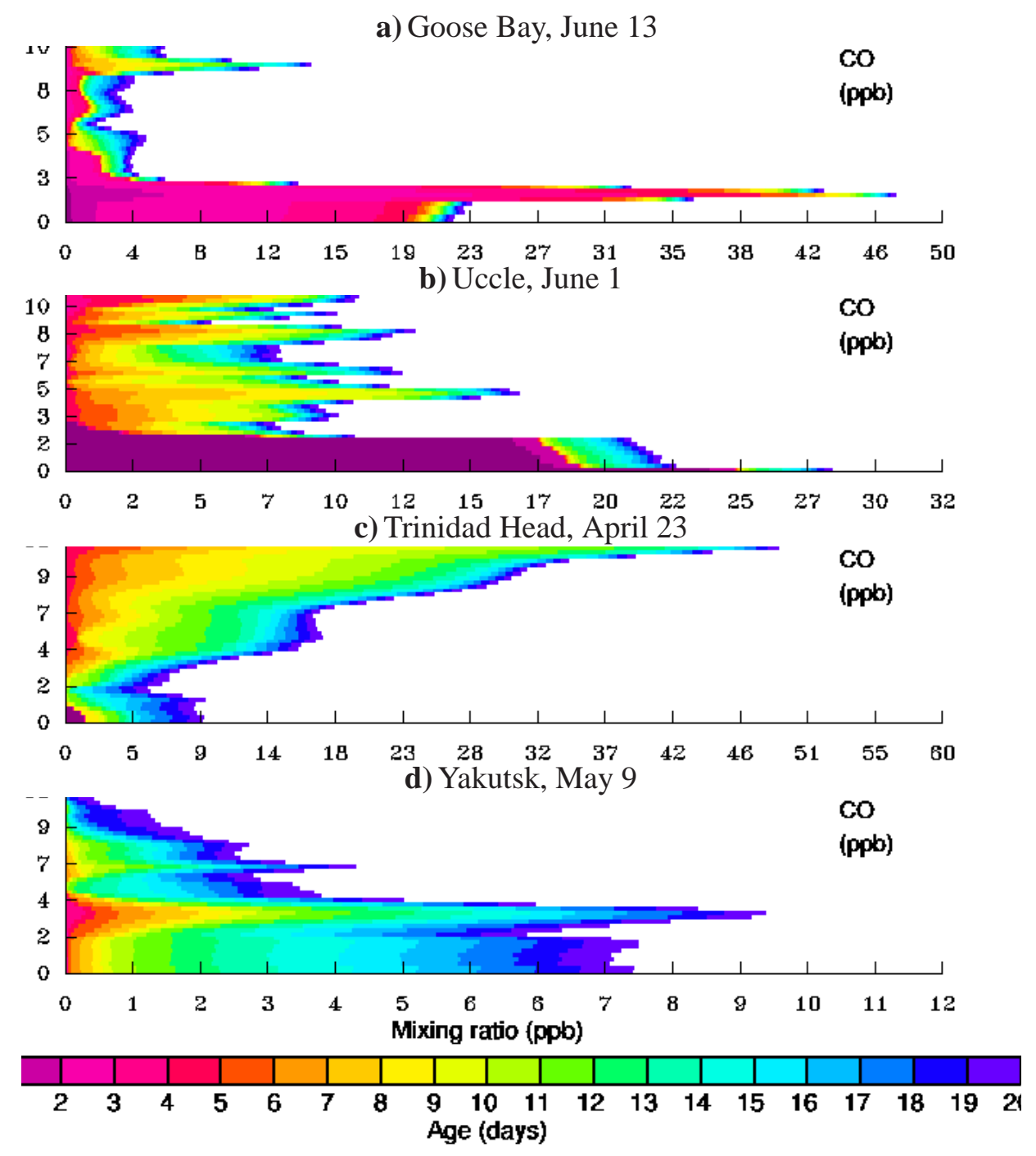

Fig. 16. Age spectrum, showing the enhancement of $\mathrm{CO}$ due to emissions over the last 20 days for Goose Bay, Uccle, Trinidad Head and Yakutsk for the same dates as shown in Figs. 13-15.

troposphere to the receptor sites. The selected episode with advection to Yakutsk is characterised by shallower advection and a much smaller signal.

\section{Conclusions}

When averaging over an ensemble, numerical simulations are capable to reproduce the ozone climatology in the free troposphere in the Northern Hemisphere. At the same time the models have limited abilities in reproducing the day by day variability in ozone. For the models to reproduce the daily variability of ozone at the same level of detail as for surface sites require accurate calculations describing the development of ozone plumes over days to weeks or longer, at the limit of the capabilities of present CTM's and also at the limit of the capabilities of the underlying numerical weather prediction models. The study shows, that the capabilities of the individuals models to describe day to day ozone variability strongly depends on the individual model, yielding for some models poor correlations which needs further study.

Comparing model-calculated vertical profiles with ozonesonde measurements, there are clear indications that this ability is partially determined by the distance to the dominant source region(s) affecting ozone at the individual site and level. As an example the highest correlations are calculated for Goose Bay. As shown in Sect. 4.2, the major model-calculated source regions to this site are within the NA region, close enough to maintain the identity of the plumes, and thus the relatively short distance makes it easier for the models to determine source receptor relationships. 


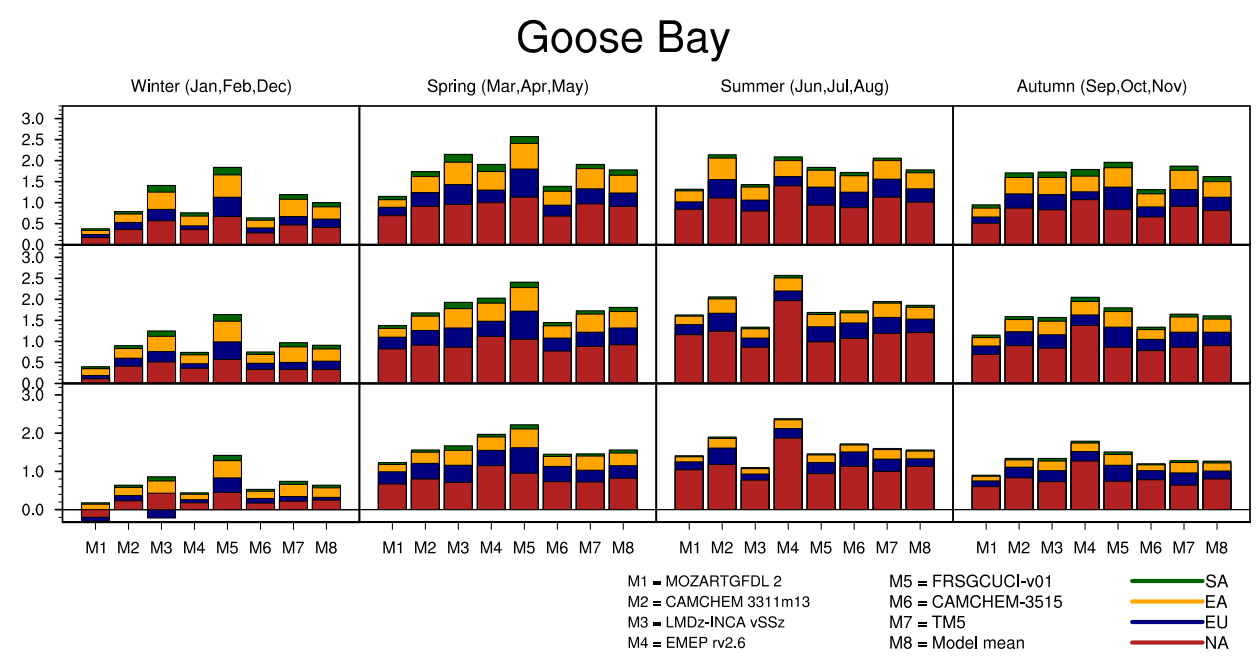

Fig. 17. Effects above Goose Bay on $\mathrm{O}_{3}(\mathrm{ppb})$ of $20 \%$ reductions in emissions in the four source regions in winter, spring, summer and autumn calculated with the first seven models (and the model mean) listed in Table 1 (see legend above). Results are aggregated to LT (900-700 hPa), MT (700-500 hPa) and UT (500-300 hPa).

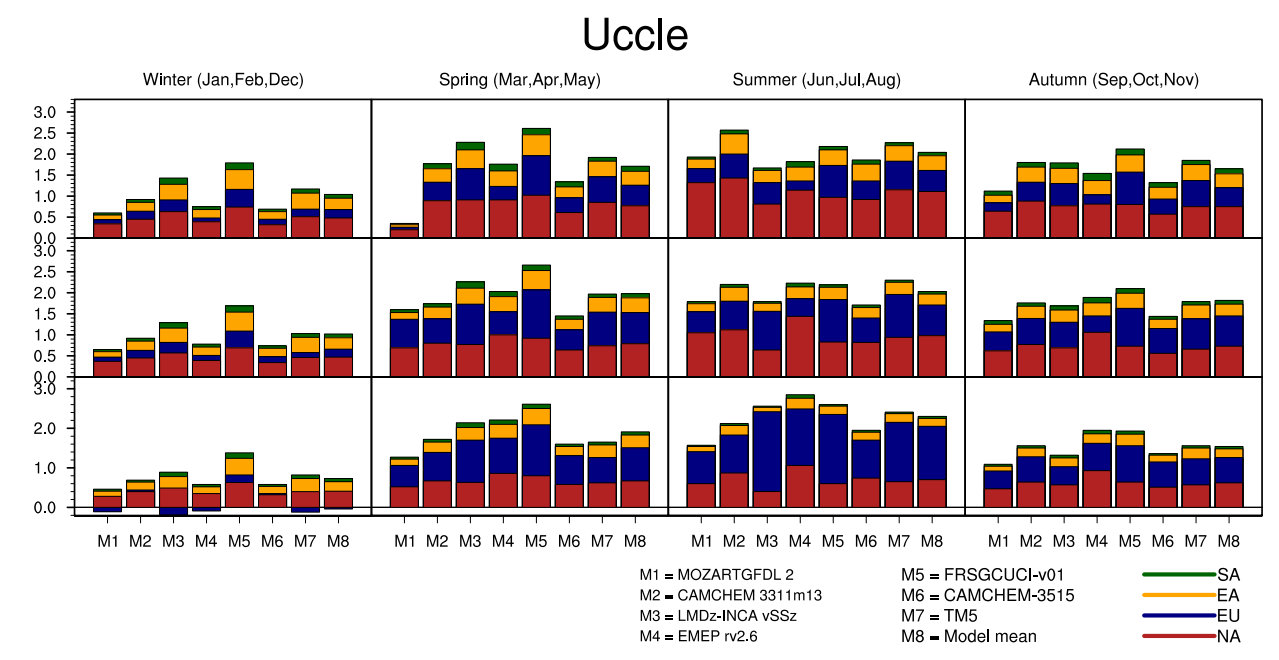

Fig. 18. Effects above Uccle on $\mathrm{O}_{3}$ (ppb) of $20 \%$ reductions in emissions in the four source regions in winter, spring, summer and autumn calculated with the first seven models (and the model mean) listed in Table 1 (see legend above). Results are aggregated to LT (900-700 hPa), MT (700-500 hPa) and UT (500-300 hPa).

As demonstrated in Sects. 4.1.2 and 4.1.3 for the selected days the effects of North American emissions on ozone above Uccle and East Asian emissions above Trinidad Head were predominantly restricted to the free troposphere. For Trinidad Head the transcontinental contributions calculated here for the three height levels are markedly higher than the contribution to The Northwest and California regions at the surface based on the same dataset in Reidmiller et al. (2009). A less frequent and dilute impact at the surface compared to the free troposphere was also seen by Zhang et al. (2009), comparing advection to Mt. Bachelor at $2.7 \mathrm{~km}$ altitude, and to Trinidad Head at sea level.
As discussed in Sect. 4.2 the transcontinental contribution of ozone in the free troposphere is larger, and with a different seasonality, compared to what was calculated for the surface in Fiore et al. (2009) and Reidmiller et al. (2009). In summer the loss rates in the boundary layer are high and ozone will not be advected between continents at this level. As a result of convection in the eastern parts of the continents, air rich in ozone and ozone precursors is lifted to high altitudes in summer and advected across the Atlantic/Pacific oceans. A major portion of the exchange of ozone between the continents take place at high altitude and here advection is not significantly weakened in summer, but as (excess) ozone is mixed down 


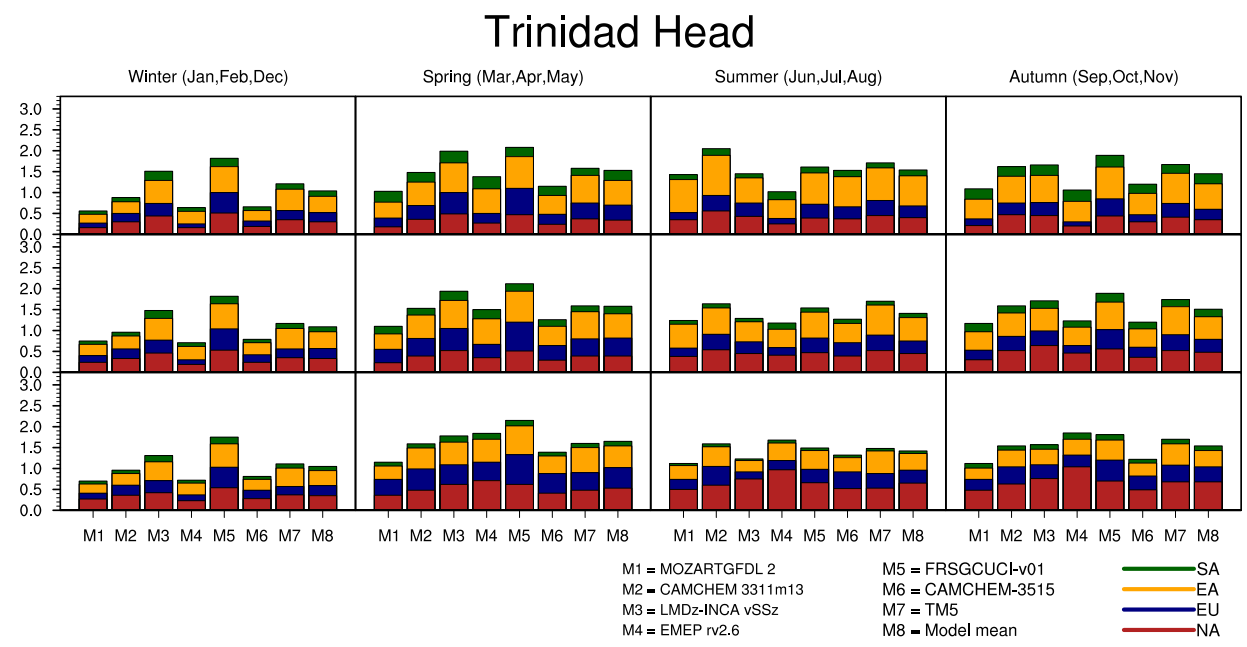

Fig. 19. Model-calculated effect above Trinidad $\mathrm{Head}$ on $\mathrm{O}_{3}(\mathrm{ppb})$ of $20 \%$ reductions in emissions in the four source regions in winter, spring, summer and autumn calculated with the first seven models (and the model mean) listed in Table 1 (see legend above). Results are aggregated to LT (900-700 hPa), MT (700-500 hPa) and UT (500-300 hPa).

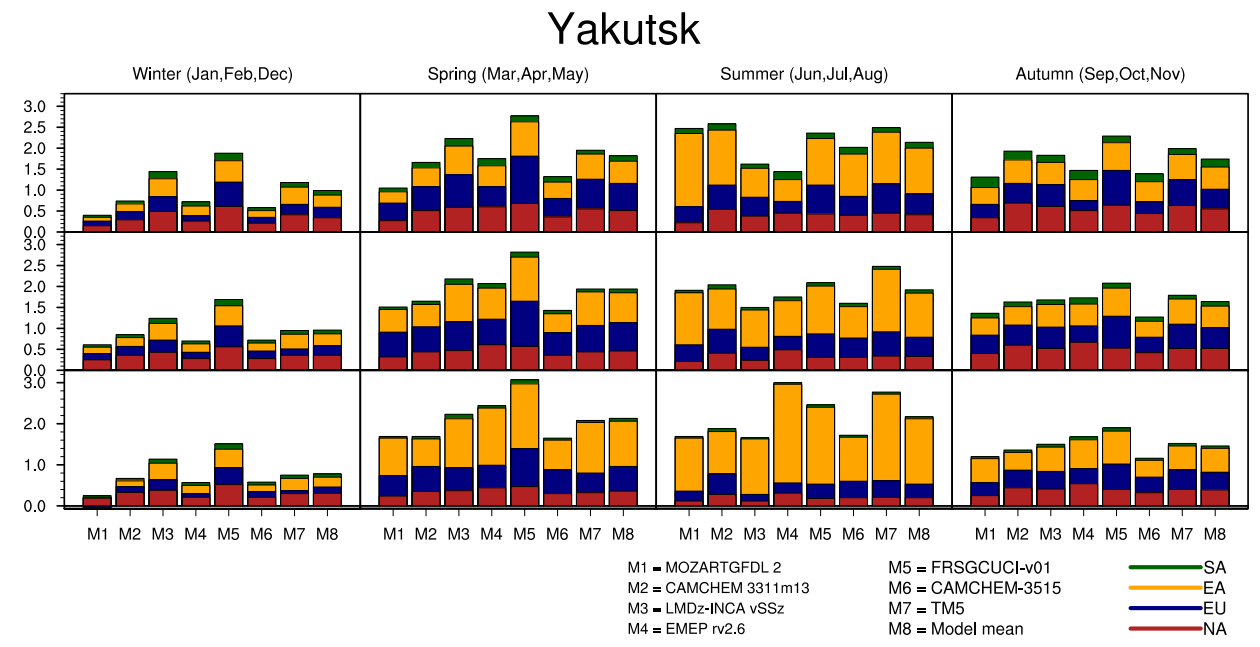

Fig. 20. Model-calculated effect above Yakutsk on $\mathrm{O}_{3}(\mathrm{ppb})$ of $20 \%$ reductions in emissions in the four source regions in winter, spring, summer and autumn calculated with the first seven models (and the model mean) listed in Table 1 (see legend above). Results are aggregated to LT (900-700 hPa), MT (700-500 hPa) and UT (500-300 hPa).

into the boundary layer it is partially lost through surface deposition and chemistry. Mixing of ozone between the boundary layer and free tropospheric air as air masses are advected across the North American continent could be the reason for difference in seasonality between Trinidad Head and Goose Bay as discussed in Sect. 4.2.

The attribution of the effects on ozone to the source regions by the TF HTAP models is corroborated by the FLEXPART retroplume calculations. For the appropriate height levels where the effects of emission reductions in one of the four regions are seen in the HTAP model-calculations, the retroplume calculations also indicates a marked contribution from the same area. But as the plumes are advected over long distances they eventually lose their identity as individual plumes and can no longer be traced back to their exact origin as demonstrated by the FLEXPART retroplume calculations. The retroplume eventually splits into multiple pathways and the tracer can no longer be ascribed to any given source region with any degree of certainty. Calculated difference in vertical ozone profiles shows that even so there is virtually always a difference between the reference SRref and the SR20\% scenarios. This excess ozone may be viewed as contributing to the persistent background ozone encircling the northern mid latitudes as a whole. The hypothesis above will need further study. 
The calculated effects of $20 \%$ reductions in the emissions in the four selected regions result in transcontinental reductions in free tropospheric ozone often in the $0.5-1 \mathrm{ppb}$ range, with seasonal contributions for some models and sites well above $1 \mathrm{ppb}$. Scaling the $20 \%$ emission perturbations to $100 \%$ (as in Figs. 7 to 10) suggests that the total contributions from transcontinental transport are of the order of 2.5$5 \mathrm{ppb}$. However, the ozone chemistry is strongly non-linear, so these contributions may in fact be larger. Derwent et al. (2004) compared a tracer labelling technique with the effects of 50\% reductions in emissions in North America and Asia. They found that the tracer labelling technique gave higher estimates, and argues that this gives a more realistic quantification of intercontinental transport. On the other hand, using percentage reductions in the source regions gives a more policy relevant quantification by describing potential responses to emission control.

Even though all models agree that there are marked transcontinental contributions, there are large differences between the individual models. Large differences between the models was also found in the assessment of pollution transport to the Arctic (Shindell et al., 2008). When comparing the outflow from the East Asian continent calculated with a global and two regional models Lin et al. (2010) argue that the finer scale regional models are better at capturing the rapid deep convection that develops along the leading edge of the convergence band during frontal events, resulting in stronger fluxes. The models included in this study, having different resolutions, are not conclusive if the magnitude of the transcontinental contributions can be linked to model resolution. Further analysis is required to unveil the reasons for these differences. When comparing the effects of emission reductions in the regions in Figs. 17 to 20 to the bias in Figs. 3 to 6 there is no apparent connection between model bias and the magnitude in the response to the SR20\% reductions in the emissions of ozone precursors, confirming the results of Fiore et al. (2009) when comparing model results with surface-ozone measurements over the eastern United States and model response to emission changes.

The use of ensemble models often result in better agreements with measurements, and as such may give more reliable predictions. But more reliable predictions can only be achieved by further improvements in the individual models included in the ensemble mean. This can only be achieved by carefully evaluating model performance for all available species and measurement platforms. In particular it is very difficult to evaluate the reliability of the model results concerning intercontinental ozone transport, as the calculated perturbations in ozone are in the range of percents (or less), and the spread in model predictions are of the same order.

Clearly more work is needed to improve the predictive potentials of the models through evaluation comparing with measurements of all available species measurement platforms. Differences in magnitude between the models are results of complicated interactions between advection, in- cluding vertical exchange processes, and chemistry involving species with a wide range of chemical lifetimes. It may however prove difficult to identify direct observational-based constraints alone to select the models that best represent hemispheric ozone transport. In addition the parameterisation of these processes should be compared separately in the models. A total of 19 global models (several of them included in this study) have provided model results for a chemical tracer experiments with tracer lifetimes ranging from 50 days (CO like) to a few days (VOC like). This tracer experiment may help explain some of the differences between the models. One option to further untangle these differences could be a proposed transition to reality model experiment, extending the tracer experiment by adding more chemistry, successively bringing these runs into closer alignment with real tropospheric chemistry calculations as simulated during the standard SRref simulation of HTAP. The differences between the models will then escalate as more detail is included in the calculations, and help determining the main processes causing the large spread in model results.

Several companion papers are already published based on the datasets in the HTAP database, and several additional papers are in progress. Furthermore a final report from the TF HTAP task force will be published in 2010 synthesising the findings from these publications.

\section{Supplementary material related to this article is available online at: http://www.atmos-chem-phys.net/10/5759/2010/ acp-10-5759-2010-supplement.pdf.}

Acknowledgements. This work was supported by the Co-operative Programme for Monitoring and Evaluation of the Long-range Transmission of Air pollutants in Europe (EMEP) under UNECE. We would like to thank Åsmund Fahre Vik, NILU and Johannes Stähelin, ETH Zürich, for valuable advice on the interpretation of ozonesonde data. We would also like to thank WOUDC for making the ozonesonde measurements available. The ozone sounding program in Uccle is supported by the Solar-Terrestrial Centre of Excellence, a research collaboration established by the Belgian Federal Government through the action plan for reinforcement of the federal scientific institutes (decision council of ministers taken on $22 / 03 / 2006$ ).

Edited by: A. S. H. Prévôt 


\section{References}

Auvray, M. and Bey, I.: Long-range transport to Europe: Seasonal variations and implications for the European ozone budget, J. Geophys. Res., 110, D11303, doi:10.1029/2004JD005503, 2005.

Casper-Anenberg, S., West, J., Fiore, A., Jaffe, D., Prather, M., Bergman, D., Cuvalier, K., Dentener, F., Duncan, B., Gauss, M., Hess, P., Jonson, J., Lupu, A., MacKenzie, I., Marmer, E., Park, R., Sanderson, M., Schultz, M., Shindell, D., Szopa, S., Vivanco, M., Wild, O., and Zeng, G.: Intercontinental impacts of ozone pollution on human mortality, Environ. Sci. Tech., 43, 17, doi: 10.1021/es900518, 2009.

Derwent, R., Stevenson, D., Collins, W., and Johnson, C.: Intercontinental transport and the origins of the ozone observed at surface sites in Europe, Atmos. Envir., 38, 1891-1901, 2004.

Deshler, T., Mercer, J., Smit, H., Stubi, R., Levrat, G., Johnson, B., Oltmans, S., Kivi, R., Thompson, A., Witte, J., Davies, J., Schmidlin, F., Brothers, G., and Sasaki, T.: Atmospheric comparison of electrochemical cell ozonesondes from different manufacturers, and with different cathode solution strengths: The Ballon Experiment on Standards for Ozonesondes, J. Geophys. Res., 113, D04307, doi:10.1029/2007JD008975, 2008.

ECMWF: P.W. White (ed.): IFS Documentation, ECMWF, Reading, UK, Available from:, http://www.ecmwf.int/research/ ifsdocs/CY25r1/index.html, 2002.

Fiore, A., Dentener, F., Wild, O., Cuvelier, C., Schultz, M., Textor, C., Schulz, M., Atherton, C., Bergmann, D., Bey, I., Carmichael, G., Doherty, R., Duncan, B., Faluvegi, G., Folberth, G., Garcia Vivanco, M., Gauss, M., Gong, S., Hauglustaine, D., Hess, P., Holloway, T., Horowitz, L., Isaksen, I., Jacob, D., Jonson, J., Kaminski, J., keating, T., Lupu, A., MacKenzie, I., Marmer, E., Montanaro, V., Park, R., Pringle, K., Pyle, J., Sanderson, M., Schroeder, S., Shindell, D., Stevenson, D., Szopa, S., Van Dingenen, R., Wind, P., Wojcik, G., Wu, S., Zeng, G., and Zuber, A.: Multi-model estimates of intercontinental source-receptor relationships for ozone pollution, J. Geophys. Res., 114, D04301, doi:10.1029/2008JD010816, 2009.

Holzer, M., Hall, T., and Stull, R.: Seasonality and weatherdriven variability of transpacific transport, J. Geophys. Res., 110, D23103, doi:10.1029/2005JD006261, 2005.

Huntrieser, H., Heland, J., Schlager, H., Forster, C., Stohl, A., Aufmhoff, H., Arnold, F., Scheel, H. E., Campana, M., Gilge, S., Eixmann, R., and Cooper, O.: Intercontinental air pollution transport from North America to Europe: Experimental evidence from airborne measurements and surface observations Seasonality and weather-driven variability of transpacific transport, J. Geophys. Res., 110, D01305, doi:10.1029/2004JD005045, 2005.

Liang, Q., Jaegle, L., Jaffe, D., Weiss-Penzias, P., and Heckman, A.: Long-range transport of Asian pollution to the northeast Pacific: Seasonal variations and transport pathways of carbon monoxide, J. Geophys. Res., 109, D23S07, doi:10.1029/2003JD004402, 2004.

Lin, M., Holloway, T., Carmichael, G. R., and Fiore, A. M.: Quantifying pollution inflow and outflow over East Asia in spring with regional and global models, Atmos. Chem. Phys., 10, 42214239, doi:10.5194/acp-10-4221-2010, 2010.

Liu, G., Tarasick, D., Fioletov, V., Sioris, C., and Rochon, Y.: Ozone correlations lengths and measurement uncertainties from analysis of historical ozonesonde data in North America and Europe, J. Geophys. Res., 114, D04112, doi:10.1029/2008JD010576, 2009.
Paris, J., Ciais, P., Nedéléc, P., Ramonet, M., Belan, B., Arshinov, M., Golitsyn, G., Granberg, I., Stohl, A., and Cayez, G.: The YAK-AEROSIB transcontinental aircraft campaigns: new insights on the transport of $\mathrm{CO}_{2}, \mathrm{CO}$ and $\mathrm{O}_{3}$ accross Siberiak, Tellus, 60b, 551-568, 2008.

Reidmiller, D. R., Fiore, A. M., Jaffe, D. A., Bergmann, D., Cuvelier, C., Dentener, F. J., Duncan, B. N., Folberth, G., Gauss, M., Gong, S., Hess, P., Jonson, J. E., Keating, T., Lupu, A., Marmer, E., Park, R., Schultz, M. G., Shindell, D. T., Szopa, S., Vivanco, M. G., Wild, O., and Zuber, A.: The influence of foreign vs. North American emissions on surface ozone in the US, Atmos. Chem. Phys., 9, 5027-5042, doi:10.5194/acp-9-5027-2009, 2009.

Sanderson, M., Dentener, F., Fiore, A., Cuvelier, K., Keating, T., Zuber, A., Atherton, C., Bergmann, D., Diehl, T., Doherty, R., Duncan, B., Hess, P., Horowitz, L., Jacob, D., Jonson, J., Kaminski, J., Lupu, A., Mackenzie, I., Mancini, E., Marmer, E., Park, R., Pitari, G., Prather, M., Pringle, K., Schroeder, S., Schultz, M., Shindell, D., Szopa, S., Wild, O., and Wind, P.: A multi-model study of the hemispheric transport and deposition of oxidised nitrogen, Geophys. Res. Lett., 35, L17815, doi:10.1029/2008GL035389, 2008.

Shindell, D., Chin, M., Dentener, F., Doherty, R., Faluvegi, G., Fiore, A., Hess, P., Koch, M., MacKenzie, I., Sanderson, M., Schultz, M., Schulz, M., Stevenson, D., Teich, H., Textor, C., Wild, O., Bergmann, D., Bey, I., Bian1, H., Cuvelier, C., Duncan1, B., Folberth, G., Horowitz, L., Jonson, J., Kaminski1, J., Marmer, E., Park, R., Pringle, K., Schroeder, S., Szopa, S., Takemura, T., Zeng, G., Keating, T., and Zuber, A.: A multi-model assessment of pollution transport to the Arctic, Atmos. Chem. Phys., 5353-5372, 2008.

Smit, H., Straeter, W., Johnson, B., Oltmans, S., Davies, J., Tarasick, D. W., Hoegger, B., Stubi, R., Schmidlin, F., Northam, T., Thompson, A., Witte, J., Boyd, I., and Posny, F.: Assessment of the performance of ECC-ozonesondes under quasi-flight conditions in the environmental simulation chamber: Insights from the Juelich Ozone Sonde Intercomparison Experiment (JOSIE), J. Geophys. Res., 112, D19306, doi:10.1029/2006JD007308, 2007. Stevenson, D., Dentener, F., Schultz, M., Ellingsen, K., van Noije, T., Wild, O., O.Zeng, Amann, M., Atherton, C., bell, N., Bergmann, D., Bey, I., Butler, T., Cofala, J., Collins, W., Doherty, R. D. R., Drevet, J., Askes, H., Fiore, A., Hauglustaine, M. G. D., Horowitz, L., Isaksen, I., Lamarque, M. K. J., Lawrence, M., Monanaro, V., Müller, J., Pyle, G. P. M. P. J., Rast, S., Rodriguez, J. M., Sanderson, M., Savage, N., Shindell, D., Strahan, S., Sudo, K., and Szopa, S.: Multimodel ensemble simulations of present-day and near-future tropospheric ozone7, J. Geophys. Res., 111, D08301, doi:10.1029/2005JD006338, 2006.

Stohl, A. and Trickl, T.: A textbook example of long-range transport: Simultaneous observation of ozone maxima of stratospheric and North American origin in the free troposphere over Europe, J. Geophys. Res., 104, 30445-30462, 1999.

Stohl, A., Hittenberger, M., and Wotawa, G.: Validation of the Lagrangian particle dispersion model FLEXPART against large scale tracer experiment data, Atmos. Environ., 32, 4245-4264, 1998.

Stohl, A., Forster, C., Eckhart, S., Spichtinger, N., Huntrieser, H., Heland, J., Schlager, H., Wilhelm, S., Arnold, F., and Cooper, O.: A backward modeling study of intercontinental pollution trans- 
port using aircraft measurements, J. Geophys. Res., 108, 4370, doi:10.1029/2002JD002862, 2003.

Stohl, A., Forster, C., Frank, A., Seibert, P., and Wotawa, G.: Technical note: The Lagrangian particle dispersion model FLEXPART version 6.2, Atmos. Chem. Phys., 5, 2461-2474, doi:10.5194/acp-5-2461-2005, 2005.

Stohl, A., Berg, T., Burkhart, J., Fjæraa, A., Forster, C., Herber, A., Hov, Ø., Lunder, C., McMillan, W., Oltmans, S., Shiobara, M., Simpson, D., Solberg, S., Stebel, K., Ström, J., Tørseth, K., Treffeisen, R., Virkkunen, K., and Ytri, K.: Arctic smoke - record high air pollution levels in the European Arctic due to agricultural fires in Eastern Europe in spring 2006, Atmos. Chem. Phys., 7, 511-534, doi:10.5194/acp-7-511-2007, 2007.

Stübi, R., Levrat, G., Hoegger, B., Viatte, P., Staehelin, J., and Schmidlin, F.: In-flight comparison of Brewer-Mastand electrochemical concentration cell ozonesondes, J. Geophys. Res., 113, D13302, doi:10.1029/2007JD009091, 2008.

Tarasick, D., Moran, M., Thompson, A., Carey-Smith, T., Rochon, Y., Bouchet, V., Gong, W., Makar, P., Stroud, C., Ménard, S., Crevier, L., Cousineau, S., Pudykiewicz, J., Kallaur, A., Ménard, R., Robichaud, A., Cooper, O., Oltmans, S., Witte, J., Forbes, G., Johson, B., Merrill, J., Moody, J., Morris, G., Newchurch, M., Schmidlin, F., and Joseph, E.: Comparison of Canadian air quality forecast models with tropospheric ozone profile measurements above midlatitude North America during the IONS/ICARTT campaign: Evidence for stratospheric input0, J. Geophys. Res., 112, D12S22, doi:10.1029/2006JD007782., 2007.
Taylor, K.: Summarizing multiple aspects of model performance in a single diagram, J. Geophys. Res., 107, 7183-7192, 2001.

TF HTAP: Task Force on Hemispheric Transport of Air Pollution. edited by : Keating,T. J. and Zuber, A., Interim report, 2007.

The Royal Society: Ground level ozone in the 21st century: future trends, impacts and policy implications, The Royal Society, RS Policy document 15/08 (Chair Davir Fowler), available at: www. royalsociety.org, 2008.

Tong, D. and Mauzerall, D.: Spatial variability of summertime tropospheric ozone over the continental United States: Implications of an evaluation of the CMAQ model7, Atmos. Environ., 40, 3041-3056, 2006.

Wild, O., Pochanart, P., and Akimoto, H.: Trans-Eurasian transport of ozone and its precursors, J. Geophys. Res., 109, D11302, doi:10.1029/2003JD004501., 2004.

Zhang, L., Jacob, D., Kopacz, M., Henze, D., Singh, K., and Jaffe, D.: Mid-latitude tropospheric ozone columns from the MOZAIC program: climatology and interannual variability, Geophys. Res. Lett., 36, L11810, doi:10.1029/2009GL037950, 2009. 